\title{
Lithospheric mantle refertilization by DMM-derived melts beneath the Cameroon Volcanic Line-a case study of the Befang xenolith suite (Oku Volcanic Group, Cameroon)
}

\author{
Sylvin S. T. Tedonkenfack ${ }^{1,2} \cdot$ Jacek Puziewicz ${ }^{1}$ (1) Sonja Aulbach ${ }^{3,4} \cdot$ Theodoros Ntaflos $^{5} \cdot$ Mary-Alix Kaczmarek $^{6}$. \\ Magdalena Matusiak-Małek ${ }^{1} \cdot$ Anna Kukuła $^{7} \cdot$ Małgorzata Ziobro $^{1}$
}

Received: 31 October 2020 / Accepted: 13 April 2021 / Published online: 24 April 2021

(c) The Author(s) 2021

\begin{abstract}
The origin and evolution of subcontinental lithospheric mantle (SCLM) are important issues of Earth's chemical and physical evolution. Here, we report detailed textural and chemical analyses on a mantle xenolith suite from Befang (Oku Volcanic Group, Cameroon Volcanic Line), which represents a major tectono-magmatic structure of the African plate. The samples are sourced from spinel-facies mantle and are dominated by lherzolites. Their texture is cataclastic to porphyroclastic, and foliation defined by grain-size variation and alignment of spinel occurs in part of peridotites. Spinel is interstitial and has amoeboidal shape. Clinopyroxene REE patterns are similar to those of Depleted MORB Mantle (DMM) except LREEs, which vary from depleted to enriched. The A-type olivine fabric occurs in the subset of one harzburgite and 7 lherzolites studied by EBSD. Orthopyroxene shows deformation consistent with olivine. The fabric of LREE-enriched clinopyroxene is equivalent to those of orthopyroxene and olivine, whereas spinel and LREE-depleted clinopyroxene are oriented independently of host rock fabric. The textural, chemical and thermobarometric constraints indicate that the Befang mantle section was refertilised by MORB-like melt at pressures of 1.0-1.4 GPa and temperatures slightly above $1200-1275{ }^{\circ} \mathrm{C}$. The olivine-orthopyroxene framework and LREE-enriched clinopyroxene preserve the protolith fabric. In contrast, the LREE-depleted clinopyroxene, showing discordant deformation relative to the olivine-orthopyroxene protolith framework, and amoeboidal spinel crystallized from the infiltrating melt. The major element and REEs composition of minerals forming the Befang peridotites indicate subsequent reequilibration at temperatures $930-1000{ }^{\circ} \mathrm{C}$. This was followed by the formation of websterite veins in the lithospheric mantle, which can be linked to Cenozoic volcanism in the Cameroon Volcanic Line that also brought the xenoliths to the surface. This study therefore supports the origin of fertile SCLM via refertilization rather than by extraction of small melt fractions, and further emphasizes the involvement of depleted melts in this process.
\end{abstract}

Keywords Xenoliths $\cdot$ Mantle $\cdot$ Peridotites $\cdot$ Refertilization $\cdot$ Cameroon Volcanic Line

Communicated by Dante Canil.

Jacek Puziewicz

jacek.puziewicz@uwr.edu.pl

1 Institute of Geological Sciences, University of Wrocław, Wrocław, Poland

2 Department of Earth Sciences, Faculty of Sciences, University of Dschang, P.O. Box 67, Dschang, Cameroon

3 Institut für Geowissenschaften, Goethe Universität Frankfurt, Frankfurt am Main, Germany

4 Frankfurt Isotope and Element Research Center (FIERCE), Goethe-Universität Frankfurt, Frankfurt am Main, Germany
5 Department of Lithospheric Research, University of Vienna, Vienna, Austria

6 Géosciences Environnement Toulouse (GET), Observatoire Midi-Pyrénées, CNRS, CNES-IRD-Université Toulouse III, Toulouse, France

7 Institute of Geological Sciences, Polish Academy of Sciences, Warsaw, Poland 


\section{Introduction}

Subcontinental lithospheric mantle (SCLM) forms the lower, sub-Moho parts of continental plates. It is considered to be the residue after melt extraction from "fertile" primitive mantle, which subsequently was affected by metasomatism, i.e., reactive percolation of melts or fluids, which changed the composition of a protolith (e.g., Carlson et al. 2005 and references therein).

Vast knowledge on the nature of SCLM and its lateral and vertical variation is based mainly on the studies of xenoliths occurring in alkali basalts and kimberlites (e.g., Pearson et al. 2003 and references therein). They show that the SCLM underlying Archean cratons is different from that occurring beneath Proterozoic and Phanerozoic areas (e.g., Griffin et al. 2009 and references therein). The latter consists of fragments of older subcontinental \pm oceanic mantles (e.g., Boyd 1989; Aulbach 2012; Pearson and Wittig 2014) assembled during orogenic events.

The SCLM occurring beneath some continental areas has the characteristics of Mid Ocean Ridge Basalt (MORB)-source mantle, i.e., consists of lherzolites which are fertile in terms of major elements but depleted in incompatible trace elements (southern domain of French Massif Central-Lenoir et al. 2000; Downes et al. 2003;

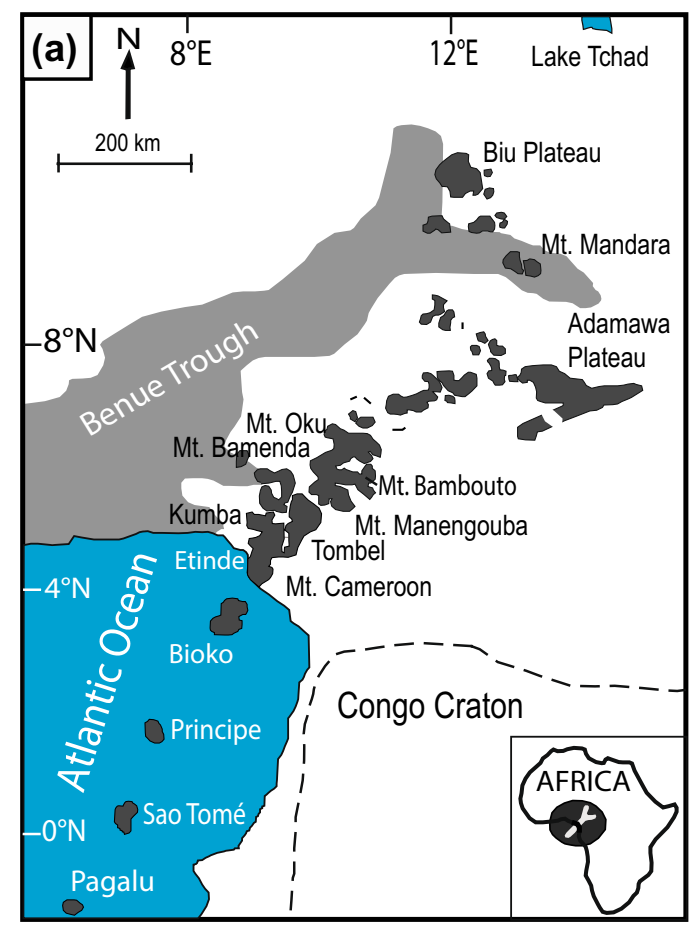

Fig. 1 a Geological sketch map of the Cameroon Volcanic Line (based on Asaah et al. 2015). Approximate extent of the Congo Craton based on Reusch et al. (2010) and Goussi Ngalamo et al. (2018).
Tariat Region, Mongolia-Carlson and Ionov 2019). By analogy with the depleted MORB-mantle, these lherzolites could be considered to represent the residuum after low-degrees of magma extraction from fertile mantle (e.g., Downes et al. 2003; Carlson and Ionov 2019). Alternatively, this kind of SCLM can originate by refertilization of harzburgites which were initially strongly depleted (e.g., Le Roux et al. 2007). Lenoir et al. (2000) suggest that LREE-depleted lherzolites of the southern domain of the French Massif Central could have originated in this way. More specifically, Puziewicz et al. (2020) showed that lherzolites forming the southern part of the French Massif Central originated by refertilization by MORB-like melts of a protolith that originally was depleted in magmaphile elements.

In this paper, we present another example of this kind of refertilized mantle. We describe the xenolith suite coming from Befang in the Oku Volcanic Group (OVG), part of the Cameroon Volcanic Line in the western part of equatorial Africa (Fig. 1a). The data presented in this paper are the first detailed account on the Befang site xenoliths. The modal composition of the xenoliths as well as the chemical characteristics of minerals are similar to those presented in prior xenolith studies in the OVG (Lee et al. 1996; Liu et al. 2017, 2020; Pintér et al. 2015; Temdjim 2012). Our study additionally takes into account the deformation fabric of

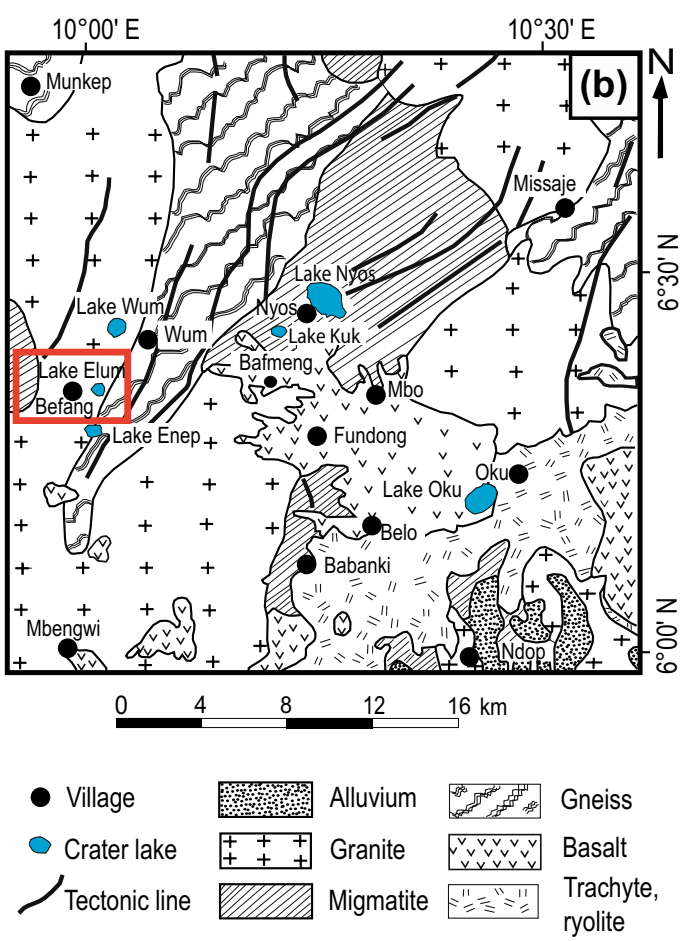

Inset shows overview of Africa with location of Cameroon Volcanic Line; b Geological sketch of the Oku Massif (based on Asaah et al. 2015) 
the xenoliths. The detailed investigation of grain alignment allows us to define the olivine-orthopyroxene framework, the deformation of which is similar in all studied xenoliths, and distinguish between clinopyroxene, deformed along with olivine and orthopyroxene from that, which post-dates this deformation. We show that the Befang mantle section was metasomatized by melts leaving a source similar to the Depleted MORB Mantle (DMM).

\section{Geological setting}

The Cameroon Volcanic Line (CVL) is the linear group of Eocene to recent volcanoes that stretches $1700 \mathrm{~km} \mathrm{SW-NE}$ from Pagalu Island in the Atlantic to the Biu Plateau and Mandara Mountains in NE Nigeria (Fig. 1). The lavas of CVL are mostly alkaline and their volume is small (Fitton 1980). The lavas with compositions ranging from basanite to hypersthene-normative basalt occur in almost all volcanic centres (Njome and de Wit 2014).

The continental part of the CVL developed on the Central African Orogenic Belt, which formed during Neoproterozoic collision of the Congo Craton with the Saharan Metacraton during assembly of Gondwana (Abdelsalam et al. 2002). The part of the Central African Orogenic Belt underlying the CVL borders the Congo Craton to the SW, and the Benue Trough to the NE (Fig. 1a).

Tomographic seismic models of O'Reilly et al. (2009) and Fishwick (2010) suggest that the upper mantle underlying CVL forms a NE-SW corridor between the Congo and the West African cratons. These models, albeit crude, suggest that the lithospheric/asthenospheric mantle analogous to that underlying the continental part of the CVL stretches to the SW beneath the Gulf of Guinea and underlies the Atlantic part of CVL.

The lithosphere-asthenosphere boundary (LAB) is located between 150 and $200 \mathrm{~km}$ beneath the Congo Craton. Beneath the Central African Orogenic Belt the LAB shallows to ca. $110 \mathrm{~km}$ (Goussi Ngalamo et al. 2018). The LAB beneath the Oku Volcanic Group is elevated to ca. 85-90 km (Goussi Ngalamo et al. 2018). The study of Gallacher and Bastow (2012) shows that the lithosphere beneath the CVL differs from that typical of hot-spots or rifts in that there is no evidence for extensive melting in the crust, or for addition of mafic intrusions to the lower/middle crust by underplating. This suggests that potential temperatures in the mantle are not increased and indicates alternative mechanisms producing small melt fractions, like shear zones or delamination (Gallacher and Bastow 2012).

The Oku Volcanic Group (OVG; $9^{\circ} 54^{\prime}$ to $10^{\circ} 50^{\prime} \mathrm{E}, 6^{\circ} 00^{\prime}$ to $\left.6^{\circ} 40^{\prime} \mathrm{N}\right)$ culminating at Mt. Oku (3011 m asl) is one of the four major volcanic centres in the continental sector of CVL (Asaah et al. 2015). The OVG consists of four stratovolcanoes (Mts. Oku, Babanki, Nyos and Nkambe), where volcanic rocks ( 30 to $<1 \mathrm{Ma}$; Njome and de Wit 2014) have compositions ranging from basanite to trachyte and rhyolite (Asaah et al. 2015 and references therein).

\section{Previous xenolith studies in the Oku Volcanic Group}

Lee et al. (1996) presented the first set of peridotite data from the continental sector of the CVL including three xenoliths from OVG and reporting mineral major and trace element contents. Lee et al. (1996) showed that the xenolith minerals are fertile in terms of major elements and that clinopyroxenes from Mt. Cameroon, Mt. Oku and Biu Plateau have REE patterns which are LREE-depleted, REE-enriched or HREE-depleted. They suggested that the xenoliths record melt extraction followed by metasomatism. Lee et al. (1996) further reported the occurrence of small amounts of amphibole in some of xenoliths, which they interpreted to be of synvolcanic origin.

The other published xenolith data from the OVG refer to the Lake Nyos site (Liu et al. 2017, 2020; Pintér et al. 2015; Temdjim 2012), which is located several kilometres from Befang (Fig. 1b). Part of the Nyos lherzolites contain subordinate amphibole (Liu et al. 2017; Pintér et al. 2015; Temdjim 2012). Analyses of minerals from xenoliths occurring in the OVG were presented in a study of Matsukage and Oya (2010). All these studies document prevailing lherzolite modal compositions of xenoliths and fertile mineral major element compositions.

The REE patterns of clinopyroxene from Nyos xenoliths were shown to be flat except LREE, which vary from LREEdepleted to LREE-enriched (Liu et al. 2017, 2020; Pintér et al. 2015; Temdjim 2012). Liu et al. (2017) report additionally MREE-LREE-depleted clinopyroxene in one xenolith, and Temdjim (2012) reports two xenoliths containing clinopyroxene with REE increasing steadily from HREE to REE with a hump at Ce.

Pintér et al. (2015) and Temdjim (2012) argue for melt depletion followed by silicate melt metasomatism, whereas Liu et al. (2020) conclude that the SCLM beneath Lake Nyos was subjected to low degree of melting and subsequent metasomatism by carbonated silicate melt. Conversely, Liu et al. (2017) suggest metasomatism partly by silicate melt and partly by carbonatite. These latter two studies also reach conflicting conclusions regarding the age of lithosphere stabilization. Based on Re-Os and $\mathrm{Lu}-\mathrm{Hf}$ isotope compositions of Lake Nyos xenoliths, with $\mathrm{T}_{\mathrm{RD}} \mathrm{Re}-\mathrm{Os}$ ages between 0.02 and $1.19 \mathrm{Ga}$, Liu et al. (2020) concluded that the lithosphere was affected by melt depletion at $\sim 2.0 \mathrm{Ga}$. In contrast, Liu et al. (2017) presented $\mathrm{Re}-\mathrm{Os} \mathrm{T}_{\mathrm{RD}}$ ages varying between 0.12 and $2.05 \mathrm{Ga}$, but proposed that the age of depletion 
is ca. $2.6 \mathrm{Ga}$, based on the initial ${ }^{187} \mathrm{Os} /{ }^{186} \mathrm{Os}$ and resultant $\mathrm{T}_{\mathrm{RD}}$ age yielded by a correlation of ${ }^{187} \mathrm{Os} /{ }^{186} \mathrm{Os}$ with $\mathrm{Al}_{2} \mathrm{O}_{3}$.

\section{Sampling, analytical methods, nomenclature}

\section{Sampling}

The xenolith suite described in this study comes from a morphologically recent ( $<1 \mathrm{Ma}$ ) pyroclastic cone located in Befang village in the Oku Massif (Electronic Supplementary Material 1). The cone, which is cut due to quarrying, consists of ash, lapilli, bombs and granite-gneiss and mantle xenoliths, which range in size from few to ca $20 \mathrm{~cm}$. We collected 46 xenoliths, and after rejecting those which were strongly weathered, 27 were chosen to make thick $(100 \mu \mathrm{m})$ sections. After microscopic examination, 16 unweathered sections representing the whole textural spectrum occurring in the xenoliths were chosen for detailed studies. Modal compositions were determined on high-resolution images of thick sections by point-counting using JMicrovision software and are summarized in Electronic Supplementary Material 2.

The primary minerals forming the xenoliths are described as "I" (olivine I, orthopyroxene I, etc., see also MatusiakMałek et al. 2014). Lamellae in primary minerals are referred to as "II". Minerals in fine-grained intergranular aggregates and forming reactive rims on primary ones, as well as fine interstitial grains which are compositionally similar, are "III" (Fig. 2).

When possible, we use the textural terminology of Mercier and Nicolas (1975). However, the peridotites from Befang commonly exhibit grain size reduction and other

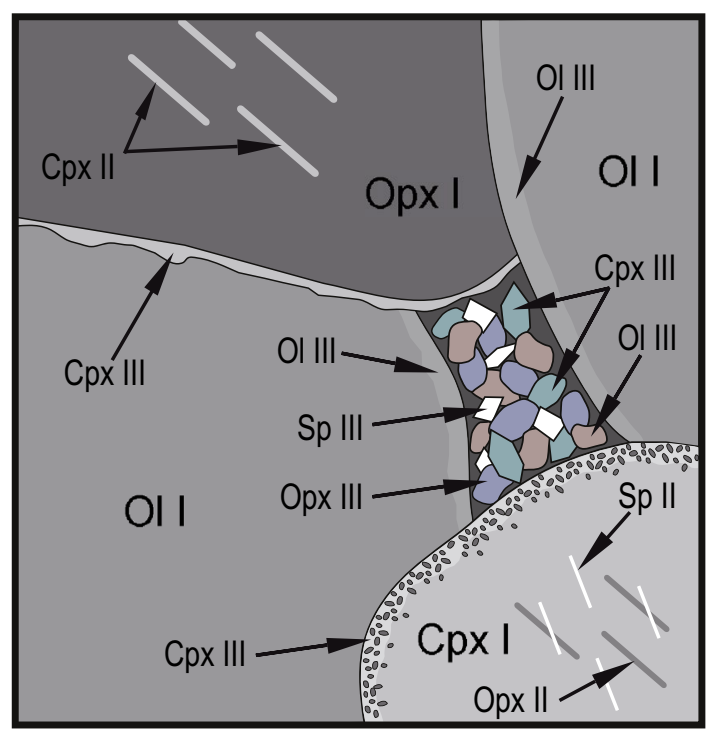

Fig. 2 The classification of peridotite minerals used in this study features typical of deformation, and for more precise description, we use the terms seriate (grain sizes continuously varying from the small ones to the large ones) and cataclastic (describing the texture which originates due to predominantly brittle grain size reduction).

\section{Electron microprobe analyses}

The major element composition of minerals was analyzed by Cameca SXFive FE electron microprobe at the Department of Lithospheric Research, University of Vienna, Austria. Acceleration voltage was $15 \mathrm{kV}$, beam current $20 \mathrm{nA}$, counting times on peak position $20 \mathrm{~s}$, background $10 \mathrm{~s}$. At least 5-10 grains of each mineral in thick section were analyzed, each grain usually in $2-4$ points to verify the compositional variation.

The counting time for $\mathrm{Ca}$ and $\mathrm{Ni}$ in olivine was slightly lengthened (peak $60 \mathrm{~s}$, background $30 \mathrm{~s}$ ), which allowed the detection limit (DL) of Ca in olivine to be ca. $160 \mathrm{ppm}$ $(0.02 \mathrm{wt} \% \mathrm{CaO})$ and that of $\mathrm{Ni} 400 \mathrm{ppm}(0.05 \mathrm{wt} \% \mathrm{NiO})$. In olivine, we analyzed also contents of $\mathrm{Ti}(\mathrm{DL} \sim 100 \mathrm{ppm}$, corresponding to $0.015 \mathrm{wt} \% \mathrm{TiO}_{2}$ ), $\mathrm{Al}$ (DL $\sim 80 \mathrm{ppm}$, corresponding to $0.015 \mathrm{wt} \% \mathrm{Al}_{2} \mathrm{O}_{3}$ ) and $\mathrm{Cr}(\mathrm{DL} \sim 135 \mathrm{ppm}$, corresponding to $0.02 \mathrm{wt} \%$ of $\mathrm{Cr}_{2} \mathrm{O}_{3}$ ).

The counting time for $\mathrm{Ni}$ in pyroxenes was $30 \mathrm{~s}$ on peak and $15 \mathrm{~s}$ on background, which resulted in detection limit of ca. $500 \mathrm{ppm}(0.06 \mathrm{wt} \% \mathrm{NiO})$. Mineral chemical data are summarized in Table 1, the source data are given in Electronic Supplementary Material 3. Forsterite content in olivine $(\mathrm{Fo})$ is calculated as atomic $100 * \mathrm{Mg} /(\mathrm{Mg}+\mathrm{Fe}+\mathrm{Mn})$ per formula unit. Spinel compositions are based on three cations, with $\mathrm{Fe}^{3+}$ and $\mathrm{Fe}^{2+}$ calculated by charge balance (Deer et al. 1992). Silica content in spinel is commonly below detection limit (240 ppm, corresponding to $0.052 \mathrm{wt} \% \mathrm{SiO}_{2}$ ). In some analyses, it is slightly above detection limit (typically $<0.10 \mathrm{wt} \% \mathrm{SiO}_{2}$, Electronic Supplementary Material 3) but for consistency we did not include it in the structural formulae. The $\mathrm{Cr}$-number ( $\mathrm{Cr} \#)$ denotes the atomic ratio of $\mathrm{Cr} /(\mathrm{Cr}+\mathrm{Al})$, and $\mathrm{Mg}$-number $(\mathrm{Mg} \#)$ denotes atomic $\mathrm{Mg} /$ $\left(\mathrm{Mg}+\mathrm{Fe}^{\text {tot. }}\right)$.

\section{LA-ICP-MS analyses}

Trace element contents in clino- and orthopyroxene were analyzed by Laser Ablation ICP-MS at the Institut für Geowissenschaften, Goethe Universität (Frankfurt am Main, Germany) using a RESOlution (Resonetics) $193 \mathrm{~nm} \mathrm{ArF}$ Excimer Laser (CompexPro 102, Coherent), operated at a laser energy of $5 \mathrm{~J} / \mathrm{cm}^{2}$ and repetition rate of $8 \mathrm{~Hz}$, coupled to a Thermo Scientific Element XR ICP-MS. Sample runs were bracketed by NIST 612 glass measurements which was used for sensitivity calibration (reference values of Jochum et al. 2011, were adopted). The Si content determined by 
Table 1 Overview of mineral chemical data for the Befang xenolith suite

\begin{tabular}{|c|c|c|c|c|c|c|c|c|c|}
\hline Sample no & Olivine Fo & $\begin{array}{l}\text { Olivine } \mathrm{NiO} \\
(\mathrm{wt} \%)\end{array}$ & $\begin{array}{l}\text { Olivine } \\
\mathrm{Ca}(\mathrm{ppm})\end{array}$ & $\begin{array}{l}\text { Orthopyroxene } \\
\mathrm{Al} \text { (a pfu) }\end{array}$ & $\begin{array}{l}\text { Clinopyroxene } \\
\mathrm{Al} \text { (a pfu) }\end{array}$ & Spinel Cr\# & $\begin{array}{l}T(\mathrm{~B} \& \mathrm{~K})^{\mathrm{a}} \\
\min -\max { }^{\circ} \mathrm{C}(n)\end{array}$ & $\begin{array}{l}T(\mathrm{~B} \& \mathrm{~K})^{\mathrm{b}} \\
{ }^{\circ} \mathrm{C}\end{array}$ & $\begin{array}{l}T(\mathrm{~L}) \\
{ }^{\circ} \mathrm{C}\end{array}$ \\
\hline BFA3 & 89.3 & 0.37 & $250-400$ & 0.177 & 0.297 & 0.11 & 946-976 (18) & 959 & $967 \pm 6$ \\
\hline BFA7 & 90.0 & 0.39 & $450-690$ & 0.177 & 0.281 & 0.11 & $948-973$ (17) & 968 & $972 \pm 7$ \\
\hline BFA16 & 89.1 & 0.38 & $280-570$ & 0.188 & 0.300 & 0.09 & 970-996 (11) & 987 & $999 \pm 6$ \\
\hline BFA17 & 89.9 & 0.39 & $420-650$ & 0.176 & 0.289 & 0.09 & $970-987(22)$ & 984 & $971 \pm 6$ \\
\hline BFA23 & 89.5 & 0.39 & $300-490$ & 0.178 & 0.300 & 0.09 & $925-944(16)$ & 930 & $942 \pm 5$ \\
\hline BFA28 & 89.6 & 0.39 & $580-750$ & 0.190 & 0.281 & 0.09 & 969-1006 (13) & 983 & $1004 \pm 7$ \\
\hline BFA29 & 88.7 & 0.38 & $380-530$ & 0.181 & 0.286 & 0.09 & $946-973(20)$ & 956 & $964 \pm 6$ \\
\hline BFA31 & 89.8 & 0.38 & $450-680$ & 0.175 & 0.284 & 0.11 & 980-998 (15) & 997 & $993 \pm 7$ \\
\hline BFA33 & 89.2 & 0.38 & $180-400$ & 0.175 & 0.278 & 0.11 & $947-974(45)$ & 953 & $949 \pm 7$ \\
\hline BFA35 & 89.8 & 0.39 & $450-730$ & 0.181 & 0.296 & 0.10 & $962-981(44)$ & 965 & $967 \pm 5$ \\
\hline BFA36 & 90.1 & 0.39 & $550-750$ & 0.171 & 0.250 & 0.15 & No equilibrium, (43) & - & - \\
\hline BFA42 & 89.8 & 0.38 & $220-420$ & 0.169 & 0.275 & 0.11 & No equilibrium, (27) & - & - \\
\hline BFA43 & 89.4 & 0.38 & $450-750$ & 0.180 & 0.291 & 0.10 & No equilibrium, (28) & - & - \\
\hline BFAx & 89.7 & 0.37 & $260-500$ & 0.177 & 0.292 & 0.11 & 962-984 (9) & 968 & $962 \pm 6$ \\
\hline BFA24* & 90.3 & 0.39 & $200-400$ & 0.151 & 0.244 & 0.19 & 930-948 (20) & 938 & $935 \pm 6$ \\
\hline BFA13** & - & - & - & 0.154 & 0.226 & - & $925-948(30)$ & 936 & $1104 \pm 9$ \\
\hline
\end{tabular}

All samples have herzolite composition except * (harzburgite) and ** (websterite)

$F o$ forsterite content; $a$ pfu atoms per formula unit; $C r \# \mathrm{Cr} /(\mathrm{Cr}+\mathrm{Al})$ molar; $T$ temperature of orthopyroxene-clinopyroxene equilibration; $B \& K$ calculated by method of Brey and Köhler (1990); $L$ calculated by method of Liang et al. (2013); $n$ number of pairs used

${ }^{\mathrm{a}}$ Temperature range, pairs of ortho- and clinopyroxene

${ }^{\mathrm{b}}$ Temperature from spreadsheet of Liang et al. (2013), based on averaged mineral compositions

electron microprobe was used as internal standard. The spot diameter was 50 (clinopyroxene) or 75 (orthopyroxene) $\mu \mathrm{m}$. Basalt glass BIR1G was used to monitor accuracy and San Carlos orthopyroxene grain was used as an in-house secondary standard (Aulbach et al. 2017). Results are reported in Electronic Supplementary Material 7. The Glitter 4.0 software (van Achterberg et al. 2001) was used for raw data processing. As the reproducibility of BIR-1G was $5 \%$ or better for most elements (except $\mathrm{Be}, \mathrm{In}$ and $\mathrm{U}$ ), but the measured values of many elements of interest were low by $10-20 \%$, a correction factor was applied to the unknowns.

We analyzed at least 2-4 grains of ortho- and clinopyroxene in each thick section. If the grain size allowed, 2 or 3 points in each grain were analyzed (margin, center and one point between). Trace element and REE contents were normalized to primitive mantle (PM) using values of McDonough and Sun (1995). The REE patterns of clinopyroxene are identical at the scale of individual grains and of multiple grains within a sample, apart from small variation in $\mathrm{La}$ and $\mathrm{Ce}$ in some of the samples (e.g., BFA35, Electronic Supplementary Material 6). Other exceptions are clinopyroxene grains from lherzolites BFA29 and BFA33, which show slight variation from La to Sm or Eu. Trace element patterns of clinopyroxene further exhibit variations in contents of highly incompatible elements which are present in ultralow concentrations and consequently most sensitive to analytical uncertainties $(\mathrm{Rb}, \mathrm{Ba}$, $\mathrm{Th}, \mathrm{U}, \mathrm{Nb}, \mathrm{Ta})$. The same applies to orthopyroxene in most samples. The variation in REE contents is slightly greater from $\mathrm{La}$ to $\mathrm{Sm}$ or $\mathrm{Eu}$ in orthopyroxene, but is also taken to reflect scatter caused by mass spectrometer working at the limits of detection. As all these variations likely reflect measurement uncertainty, and because of the overall homogeneity, we present averages for each sample in the following. In some samples, single analytical points yield compositions, which depart from the majority of analyses. They show no systematic location relative to grain margins/centers, and we assume that they are due to contamination of analyzed spots by optically invisible alteration-filled cracks or clinopyroxene lamellae and/or intergrowths and exclude them from the averages. Representative examples of the variation of REE patterns in individual samples are given in Electronic Supplementary Material 6.

The full set of LA-ICP-MS analytical data is presented in Electronic Supplementary Material 7, in which the relative standard deviation of multiple analyses of each element in a sample is included, shown as a percent of average element concentration in the sample. Since multiple spots per grain and multiple grains per sample were analyzed, this indicates 
whether there is homogeneity both at the grain and the sample scale and allows outliers to be identified.

\section{EBSD measurements}

Electron Backscatter Diffraction (EBSD) has been performed on eight samples where olivine, pyroxenes and spinel have been analyzed. Before analysis, a mechanicchemical polishing using a Vibromet was applied for $1 \mathrm{~h}$ 15 min with a colloidal silica suspension ( $\mathrm{pH} 10)$ to remove mechanically induced surface damage. The EBSD camera HKL Advanced Nordlys Nano from Oxford Instruments is attached to a JEOL 7100 electron microscope, located at the microcharacterization centre Raimond Castaing, University Paul Sabatier, Toulouse, France. The microscope working conditions include an acceleration voltage of $20 \mathrm{kV}$, probe current of $16 \mathrm{nA}$, with a stage tilt of $70^{\circ}$ and working distance of $16 \mathrm{~mm}$. Automatic indexing was performed using AZTec software (version 3.5) from Oxford Instruments, with different settings according to the grain size. Data were processed using Channel 5 package. Measurements with a mean angular deviation greater than 1.3 were removed, and grains were then calculated by imposing an orientation difference smaller than $10^{\circ}$ for any two neighboring measurements belonging to the same grain. Grains with a surface smaller than 10 pixels were removed to avoid bias caused by potential indexing error. The maps were compared with band contrast maps to ensure that the treatment did not compromise the data. In the xenoliths, when possible, a lineation has been defined and the xenoliths have been oriented with the lineation parallel to X, within the foliation plane XY. The lineation has been defined using orthopyroxene [001] axes which are parallel to olivine [100] axes in all samples. Moreover, olivine [010] axes are perpendicular to orthopyroxene [001] axes and olivine [010] axes defining the pole to the foliation plane. The multiple uniform density (mud) and the J-index, which is the measure of the fabric strength (Bunge 1982) are reported.

\section{Petrography and mineral chemistry}

The Befang xenoliths are angular to rounded, and measure between 3 and $21 \mathrm{~cm}$ in size. The studied xenolith suite comprises 14 spinel-lherzolites, one spinel-harzburgite and one websterite (Electronic Supplementary Material 1, Fig. 3). Lherzolites are unequigranular, seriate, weakly cataclastic (Fig. 4a) to weakly porphyroclastic (Fig. 4b). They consist of a mosaic of fine grains, which enclose aggregates of slightly to significantly coarser grains (Fig. 4c). The foliation defined by the arrangement of streaks of isometric to elongated spinel grains (Fig. 4c) or by alternating layers of finer and coarser grains occurs in some rocks (Fig. 4d). Grain sizes vary from 8-9 mm (larger grains of olivine or

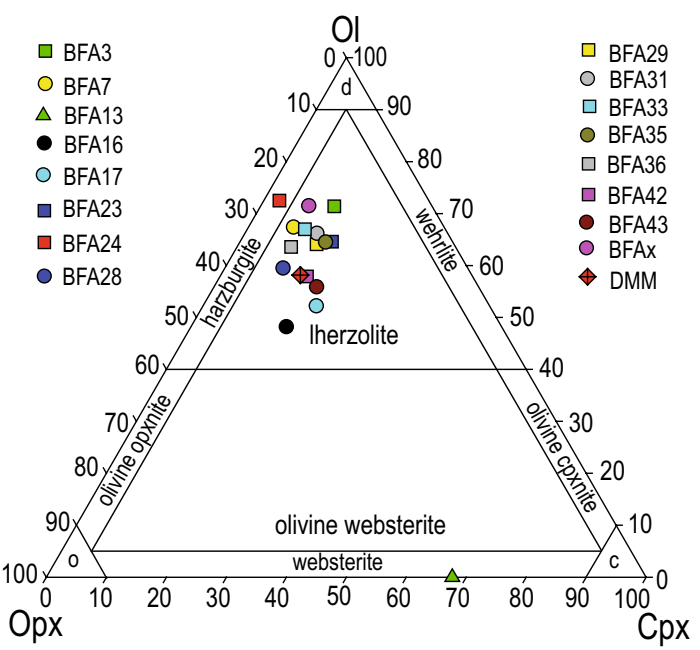

Fig. 3 Rock compositions in olivine (Ol)-orthopyroxene (Opx)clinopyroxene (Cpx) classification diagram of IUGS. DMM depleted MORB Mantle (Workman and Hart 2005); $d$ dunite; $o$ orthopyroxenite; $c$ clinopyroxenite

orthopyroxene in some rocks, Fig. 4d), through millimetric grains of all rock-forming minerals to $0.1 \mathrm{~mm}$ in fine-grained mosaic (Fig. 4). Spinel (up to $5 \mathrm{~mm}$ ) in lherzolites is texturally late, its grains are commonly interstitial and have amoeboidal to vermicular shapes (Fig. 4d). Larger grains of olivine commonly exhibit kink-bands. Orthopyroxene grains in some samples contain parallel clinopyroxene lamellae. Clinopyroxene grains are maximally up to $3.0 \mathrm{~mm}$ in size and commonly have spongy margins. Those occurring in lherzolite BFA36 contain parallel spinel lamellae.

Harzburgite BFA24 is protogranular to equigranular, olivine and orthopyroxene are up to $4-5 \mathrm{~mm}$, clinopyroxene is $\leq 1 \mathrm{~mm}$. The rock is faintly layered due to variation in grain size (Fig. 4e). Spinel is interstitial to amoeboidal similar to that occurring in lherzolites. Websterite BFA13 has fine-grained, unequigranular, mosaic texture (Fig. 4f).

Fine-grained intergranular aggregates consisting of olivine III, clinopyroxene III and decomposed remnants of glass (?) occur locally, but are not very common. Spinel at the contact with them is decomposed into aggregates of fine grains.

\section{Mineral chemistry of peridotites}

\section{Major elements}

Olivine I contains $88.7-90.3 \%$ Fo, from 0.37 to $0.39 \mathrm{wt} \%$ $\mathrm{NiO}$ (Fig. 5) and from 180 to $750 \mathrm{ppm} \mathrm{Ca} \mathrm{(Table} \mathrm{1).} \mathrm{Oli-}$ vine I grains are homogeneous in terms of forsterite content. Small and not systematic $(<0.06 \mathrm{wt} \%$; Electronic Supplementary Material 3) variations of $\mathrm{NiO}$ content occur (Fig. 5). 

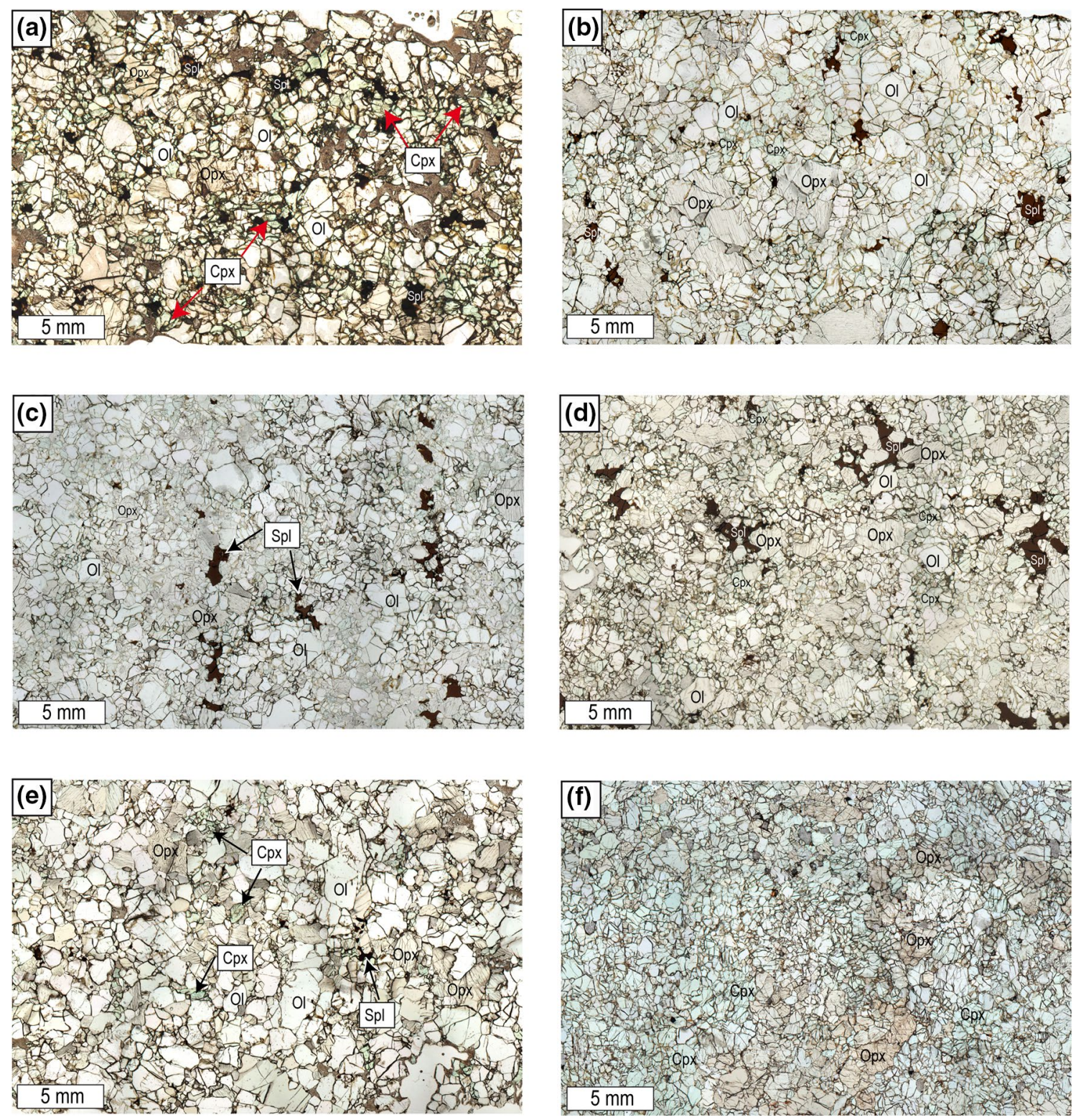

Fig. 4 Rock textures (optical images, plane-polarized light). $\mathrm{Ol}$ olivine; $O p x$ orthopyroxene; $C p x$ clinopyroxene; $S p l$ spinel. a Cataclastic texture of lherzolite BFA3; b porphyroclastic texture of lherzolite BFA42; $\mathbf{c}$ mosaic texture of lherzolite BFAx; foliation of the rock is

No inter-grain compositional variation occurs within individual samples. The variation of $\mathrm{Ca}$ content in olivine $\mathrm{I}$ is correlated with the REE characteristics of coexisting clinopyroxene (see below and Electronic Supplementary Material $3)$.

Olivine III has higher Ca content (820-1520 ppm; Electronic Supplementary Material 3) than olivine I. Olivine III forming small $(<200 \mu \mathrm{m})$ grains in the peridotites, as well as outermost rims $(<100 \mu \mathrm{m})$ of larger grains are slightly (by few tenths of percent) richer in forsterite than olivine I. They are located in contact with clinopyroxene. Olivine III defined by arrangement of spinel grains; $\mathbf{d}$ weak foliation in lherzolite BFA43 (horizontal in the image), defined by alternating layers of different grain-size; e weakly cataclastic texture of harzburgite BFA24; $\mathbf{f}$ websterite BFA13

occurring in fine-grained interstitial aggregates is richer in Fo by 0.7 to $2.3 \%$ relative to coexisting olivine I.

Orthopyroxene I (Mg\# 0.89-0.91) contains 0.171 to 0.190 atoms of $\mathrm{Al}$ per formula unit (pfu); the exception is orthopyroxene from harzburgite BFA24, which contains 0.151 atoms of $\mathrm{Al}$ pfu (Fig. 6; Table 1). Mineral grains are chemically homogeneous and their composition does not vary in individual samples (Electronic Supplementary Material 3). In lherzolites BFA31, BFA35 and BFA36, a slight increase of $\mathrm{Ca}$ contents occurs at the orthopyroxene margins in contact with clinopyroxene grains. It is best 

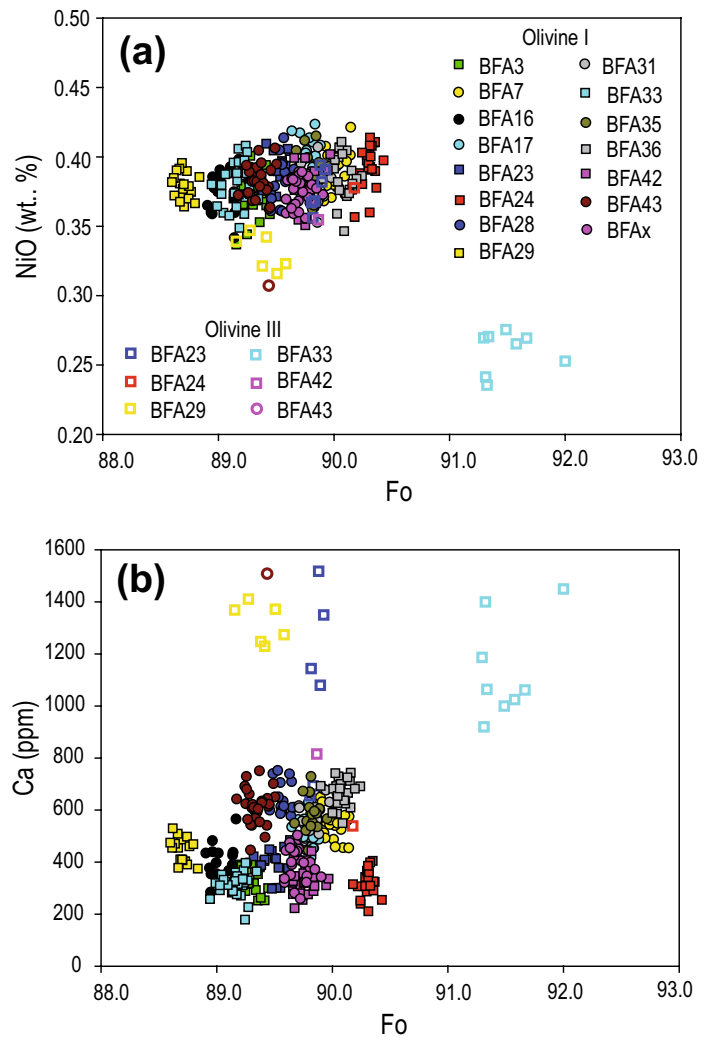

Fig. 5 Compositions of olivine I and Olivine III. a forsterite (Fo) vs. $\mathrm{NiO}$. b forsterite- $\mathrm{Ca}$. For diagram showing averages (1 point for sample) see Electronic Supplementary Material 4

expressed in lherzolite BFA36, where the rims $(\leq 100 \mu \mathrm{m}$ thick) of grains in contact with clinopyroxene are richer than centers by 0.24 atoms pfu (corresponding to 0.36 wt\% $\mathrm{CaO}$; Electronic Supplementary Material 3).

Clinopyroxene I (Mg\# 0.90-0.91) contains 0.275 to 0.300 atoms of $\mathrm{Al} \mathrm{pfu}$, with the exception of two rocks: harzburgite BFA24 (0.244) and lherzolite BFA36 $(0.250$ atoms Al pfu; Fig. 6; Table 1). Mineral grains are chemically homogeneous and show no intergranular variation in individual samples. The exception is lherzolite BFA33, in which cores of large clinopyroxene grains contain $\sim 0.50 \mathrm{wt} \%$ of $\mathrm{TiO}_{2}$, whereas their rims as well as smaller $(<0.5 \mathrm{~mm})$ grains contain $\sim 0.30-0.35 \mathrm{wt} \%$ of $\mathrm{TiO}_{2}$ (Electronic Supplementary Material 3).

Spinel I is Al-rich and chemically homogeneous at the scale of grains and samples. In lherzolites its $\mathrm{Cr} \#$ is $0.09-0.11$, the exception is lherzolite BFA36, which contains spinel of Cr\# 0.15 (Table 1). Harzburgite BFA24 contains spinel with $\mathrm{Cr} \# 0.19$ (Table 1, Fig. 6, Electronic Supplementary Material 3).

\section{Trace elements}

The REE patterns of clinopyroxene occurring in lherzolites are flat from $\mathrm{Lu}$ to $\mathrm{Eu}$, and display a spectrum from LREEdepleted to LREE-enriched $\left(\mathrm{La}_{\mathrm{N}} / \mathrm{Lu}_{\mathrm{N}}\right.$ from 0.07 to 2.58 ; subscript $\mathrm{N}$ denotes normalization to Primitive Mantle; Fig. 7). They coexist with orthopyroxene, in which the REE patterns are decreasing from $\mathrm{Lu}$ to $\mathrm{La}$. They are identical from $\mathrm{Lu}$ to Eu and differ slightly from Eu to La. The REE patterns enable to group the lherzolites into type I (LREE-impoverished patterns in clino- and orthopyroxene) and group II (LREE-enriched patterns in pyroxenes compared to those of group I; Fig. 7). Clinopyroxene from harzburgite BFA24 has an REE pattern similar to those of group I, but shifted to slightly lower values of REE (Fig. 7). The REE patterns are almost identical to that of DMM clinopyroxene (Workman and Hart 2005) in the Eu-Lu part (Fig. 7).

The trace-element patterns of clinopyroxene show weak $\mathrm{Ti}$ and $\mathrm{Pb}$ negative anomalies and well-defined negative $\mathrm{Nb}-\mathrm{Ta}$ and positive $\mathrm{Th}-\mathrm{U}$ ones (Fig. 7). Orthopyroxene is characterized by well-defined positive $\mathrm{Ti}, \mathrm{Zr}-\mathrm{Hf}$ and $\mathrm{Pb}$ anomalies (Fig. 7).

\section{Mineral chemistry of websterite}

Websterite BFA13 consists of orthopyroxene (Mg\# 0.83-0.84, 0.15-0.16 atoms of Al pfu), and clinopyroxene (Mg\# 0.84-0.85, 0.22-0.23 atoms of Al pfu; Table 1). The REE pattern of clinopyroxene exhibits enrichment from HREE towards LREE with a hump in Sm-Nd (Fig. 7). The clinopyroxene trace element pattern shows weak $\mathrm{Zr}-\mathrm{Hf}$ and Ti negative anomalies and is significantly enriched in $\mathrm{Rb}$ (Fig. 7), but does not show the Nb-Ta anomaly exhibited by clinopyroxene from lherzolites (Fig. 7). The REE patterns of orthopyroxene are variably depleted from HREE towards LREE (Fig. 7). Trace element patterns of this mineral have marked positive $\mathrm{Ti}$ and $\mathrm{Zr}-\mathrm{Hf}$ anomalies (Fig. 7).

\section{Geothermometric calculations}

Temperatures of equilibration between ortho- and clinopyroxene were calculated using the thermometer of Brey and Köhler (1990). Pressure has a small effect on calculated results (1.5 GPa was assumed), with an uncertainty of $\pm 15^{\circ} \mathrm{C}$ (Brey and Köhler 1990). We used pairs of points located in neighboring grains (margin-margin, center-center); for comparison, we calculated also the temperatures for pairs of larger grains of ortho- and clinopyroxene, which are not in direct contact, but are separated by few grains of olivine. Because in most samples ortho- and clinopyroxene I are chemically homogeneous, the temperatures 

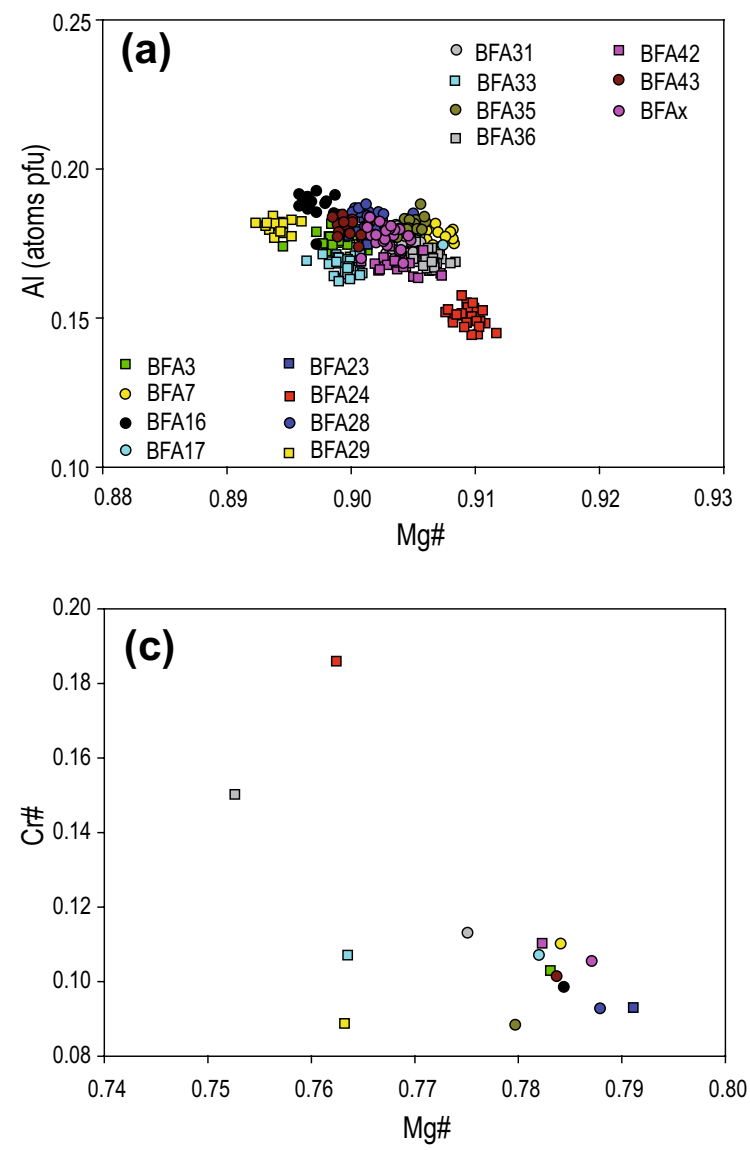

Fig. 6 Chemical parameters of primary pyroxenes and spinel from Befang peridotites and websterite. a Orthopyroxene $\mathrm{I}-\mathrm{Mg} \#$ vs. $\mathrm{Al}$; b clinopyroxene I-Mg\# vs. Al; c spinel I-Mg\# vs. Cr\#. For diagrams

in single sample show little variation $\left(14-30{ }^{\circ} \mathrm{C}\right.$, Table 1$)$. The exception is lherzolite BFA28, in which temperatures span $37^{\circ} \mathrm{C}$ (Table 1). This may be due to the small variation in the chemical composition of pyroxenes coupled with analytical uncertainties. Three of the studied rocks yielded temperatures indicating disequilibrium: BFA36 (951-1077), BFA42 (907-979) and BFA43 (951-1042 ${ }^{\circ} \mathrm{C}$ ).

We also used the thermometer of Liang et al. (2013), which calculates the temperature based on the REE contents of coexisting clino- and orthopyroxene. In their original examples, Liang et al. (2013) used averaged REE contents in ortho- and clinopyroxene in a given sample, as well as averaged major element contents for calculating temperatures according to Brey and Köhler (1990) algorithm. REE data for clinopyroxene in this study are in most cases homogeneous, which is manifested by low relative standard deviations (RSD), which are typically within few per cent (see Electronic Supplementary Material 7). By contrast, the REE contents in orthopyroxene shows significantly greater variation, resulting in RSD reaching few tens per cent for light REE (La-Gd;

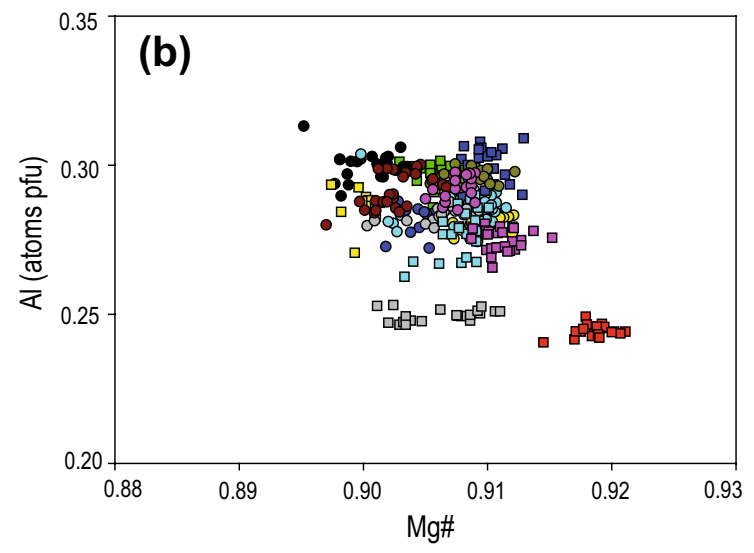

showing averages ( 1 point for sample) for ortho- and clinopyroxene see Electronic Supplementary Material 4

Electronic Supplementary Material 7). The contents of LREE are very low in orthopyroxene, and much of the variation occurring in our results is likely due to analytical uncertainties. To avoid these effects, we excluded from the calculation by Liang et al. (2013) elements whose RSD was $>10 \%$. All results are robust and all pyroxene pairs are within the calibrated $\mathrm{Mg} \#$ range according to the spreadsheet of Liang et al. (2013).

To verify this approach, we also calculated REE equilibration temperatures for individual pairs of ortho- and clinopyroxene, using mineral grains which were either in contact, or in close proximity. The representative example is lherzolite BFA17: $\mathrm{T}_{\text {REE }}$ based on averaged composition is $971{ }^{\circ} \mathrm{C}$ (Table 1), whereas the individual pairs (7 calculated) yielded values $954-972{ }^{\circ} \mathrm{C}$ except one result with $1000{ }^{\circ} \mathrm{C}\left(\mathrm{T}_{\mathrm{BKN}}\right.$ for individual mineral pairs is 970-987, and that for "averaged" composition is $984^{\circ} \mathrm{C}$ ). This example shows that the temperature calculated using averaged REE contents is representative for the individual ortho-clinopyroxene pairs. 

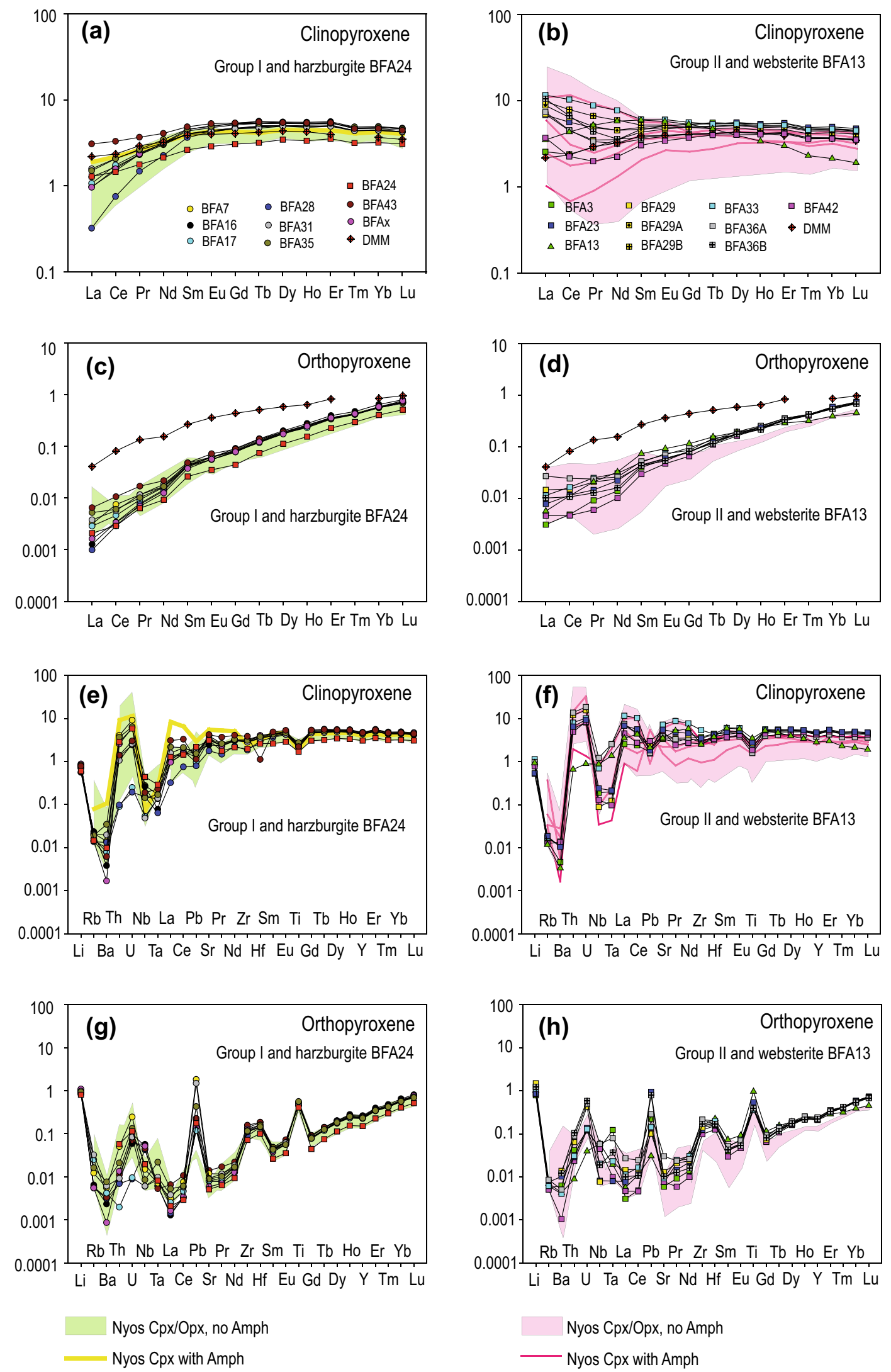
4Fig. 7 Primitive-mantle normalized (McDonough and Sun 1995) REE and trace-element patterns of pyroxenes from the Befang xenoliths. DMM (Depleted MORB Mantle; Workman and Hart 2005) clino- and orthopyroxene shown for comparison. Ranges of REE and trace elements in pyroxenes from Nyos xenoliths based on data of Liu et al. 2017, 2020; Lee et al. 1996; Pintér et al. 2015; Temdjim 2012. a, e Clinopyroxene of group I; $\mathbf{b}, \mathbf{f}$ clinopyroxene of group II; $\mathbf{c}, \mathbf{g}$ orthopyroxene of group I; $\mathbf{d}, \mathbf{h}$ orthopyroxene of group II

\section{Microstructure}

Among eight studied xenoliths, the single harzburgite shows an olivine crystal-preferred orientation (CPO) with a strong concentration of [010] axes perpendicular to the foliation plane (XY) and weak girdles on both [100] and [001] axes (Fig. 8). Only two lherzolites (BFA33 and BFA23) show olivine CPO patterns similar to those of the harzburgite, but the [100] axes show a slightly strongest concentration point parallel to $\mathrm{X}$. Three samples (BFA28, BF43, BFA16) show olivine CPO with a strong concentration point on [100] axes parallel to $\mathrm{X},[010]$ axes forming a strong concentration point perpendicular to the foliation plane and [001] a weak concentration point parallel to $\mathrm{Y}$ within the foliation plane (Fig. 8). In lherzolites BFA17 and BFA29, olivine CPO shows the strongest concentration on [100] axes parallel to X (Fig. 8). Both [010] and [001] axes form weak point concentrations parallel to $\mathrm{Z}$ or girdles within the $\mathrm{ZY}$ plane.

Orthopyroxene CPO in all studied rocks shows [001] axes parallel to the defined lineation (X) and sub-parallel to olivine [100] axes. When observable, the slip plane is either [100] in the harzburgite (BFA24), and lherzolites BFA28, BFA33, or [010] in lherzolite BFA43. For some samples, the orientation of orthopyroxene axes is more oblique and a slip plane is difficult to define (e.g., BFA29).

Clinopyroxene CPO is weaker than those of olivine and orthopyroxene. However, correlation can be observed, where clinopyroxene [001] axes, olivine [100] axes and orthopyroxene [001] axes are subparallel to $\mathrm{X}$ in three lherzolite samples (BFA23, BFA29, BFA33) and in the harzburgite BFA24 (Fig. 8). Among these samples, clinopyroxene [001] axes from BF29 show a more scattered distribution. Another group of lherzolites shows clinopyroxene [001] axes at high angle to X and both olivine [100] and orthopyroxene [001] axes (samples BFA17, BFA28, BFA43). In lherzolite BFA17, clinopyroxene [001] axes are parallel to Z, in lherzolite BFA43, they are closer to Y and in lherzolite BFA 28, they are completely scattered. It is also interesting to note that in sample BFA43, clinopyroxene [001] axes show a weak point concentration at low angle to olivine and orthopyroxene [001] axes (Fig. 8).

A closer inspection of the internal deformation of minerals using disorientation maps reveals that olivine from the harzburgite show numerous low-angle boundaries, in several orientations within one grain (Fig. 9). In the lherzolites, depending on the grain size, samples with large grains can display strong internal deformation with kink bands perpendicular to the grain elongation (e.g., BFA33), and/or weak internal deformation for smaller grains (e.g., BFA28, or BFA43) (Fig. 9). One sample (BFA29), with intermediate grain size, displays almost undeformed olivine. Orthopyroxene shows internal deformation with low-angle boundaries for large grains and weak or no deformation for smaller, recrystallized grains (not shown), a classical texture in peridotite (e.g., Toy et al. 2010; Kaczmarek and Reddy 2013). In marked contrast to olivine and orthopyroxene, clinopyroxene in all samples displays few deformed grains (up to $5^{\circ}$ ) and almost no deformation in sample BFA29 (Fig. 9).

\section{Discussion}

\section{Evolution of peridotite textures}

The studied xenoliths show grain size reduction and have cataclastic to weakly porphyroclastic textures. Some consist of weakly visible layers of different grain sizes (Fig. 4).

The CPO study shows that olivine [100] axes and orthopyroxene [001] axes are subparallel, suggesting coeval deformation because they are the dominant glide direction for these minerals. In most of the Befang lherzolites, olivine is deformed by dislocation creep and olivine CPO displays an orthorhombic symmetry with [100] axes parallel to the lineation and [010] marking a concentration point perpendicular to the lineation (parallel to Z, Fig. 8). Compared to the lherzolites, the harzburgite shows a similar olivine CPO pattern, but the concentration on [100] is weaker (Fig. 8) which is probably due to the several sets of low-angle boundaries which are the expression of multiple slip directions (Fig. 9).

The activated slip system in the olivine ((010) [100], or A-type after Jung et al. 2006) is well known to be activated in the mantle at high temperature, low stress and dry conditions (Nicolas et al. 1971; Ben Ismaill and Mainprice 1998; Karato 2008). Only sample BFA29 shows an axial-[100] olivine CPO symmetry, with [100] axes parallel to the defined lineation and [010] and [100] forming girdles perpendicular to the lineation (parallel to Z; Fig. 8). The axial-[100] fabric is typical of mantle rocks deformed at high temperature, at moderate pressure conditions, in a simple shear context (Tommasi et al. 2000; Zhang and Karato 1995; Bystricky et al. 2000). This is very similar to the conditions recorded by the rest of the xenolith suite. In most of lherzolites and the harzburgite, orthopyroxene CPO shows the activation of the (100)[001] slip system, indicating high temperature conditions.

In lherzolites BFA23, BFA29, BFA33 and in harzburgite BFA24, the clinopyroxene [001] axes are subparallel 
Fig. 8 Crystallographic preferred orientations of olivine, orthopyroxene and clinopyroxene from Befang xenoliths. Pole figures are lower-hemisphere, equal-area stereographic projection; $n$ is the number of grains and the pole figures represent one point per grain. For all pole figures, contours have been plotted at 0.5 multiples of the uniform distribution (md). The strength of the crystallographic preferred orientation (CPO) was estimated using the J-index (Bunge 1982)
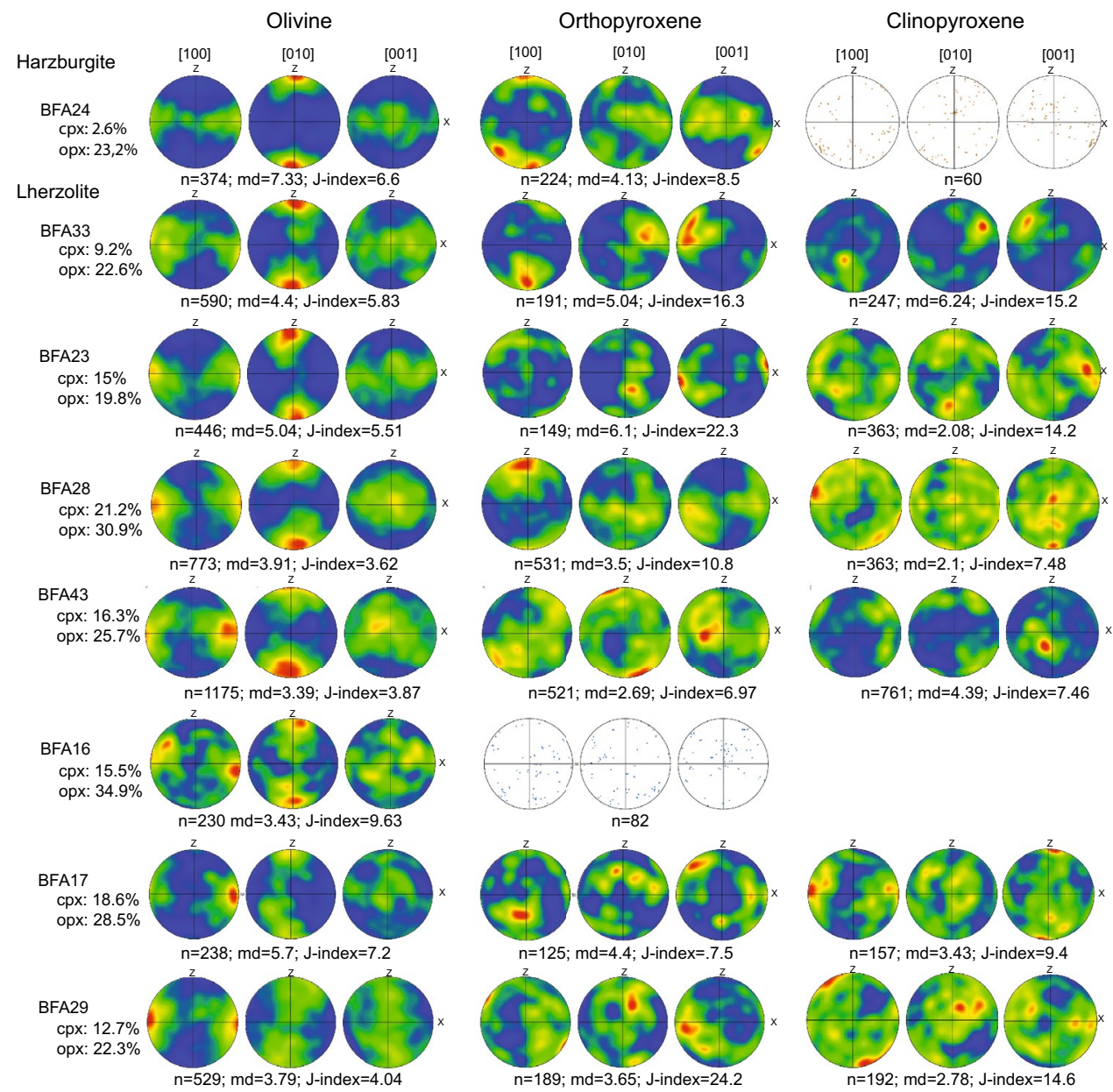

$\mathrm{n}=149 \cdot \mathrm{md}=6.1 ; \mathrm{J}$-index $=22.3$

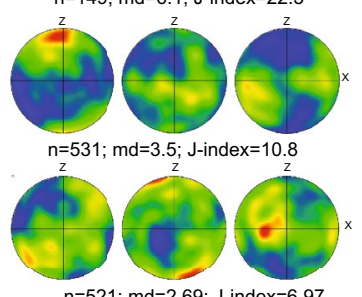

$\mathrm{n}=521 \cdot \mathrm{md}=2.69 \cdot \mathrm{J}$-index $=6.97$
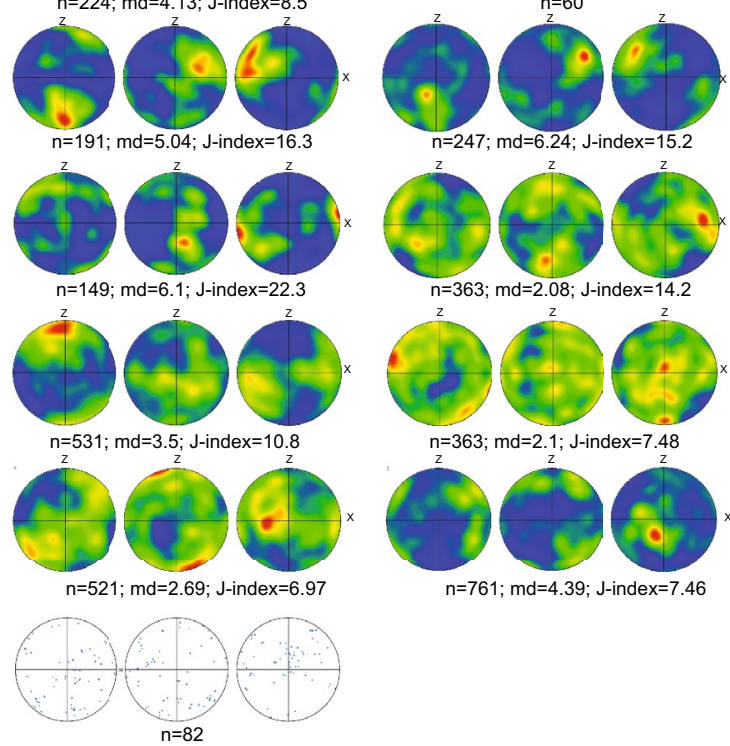

$\mathrm{n}=363 ; \mathrm{md}=2.08 ; \mathrm{J}$-index $=14$.2

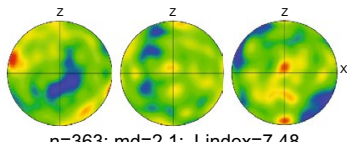

$\mathrm{n}=363 ; \mathrm{md}=2.1 ;$ J-index $=7.48$

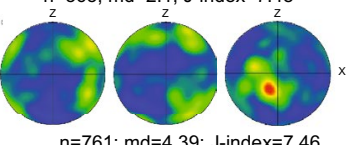

$\mathrm{n}=761 ; \mathrm{md}=4.39 \cdot \mathrm{J}$-index $=7.46$
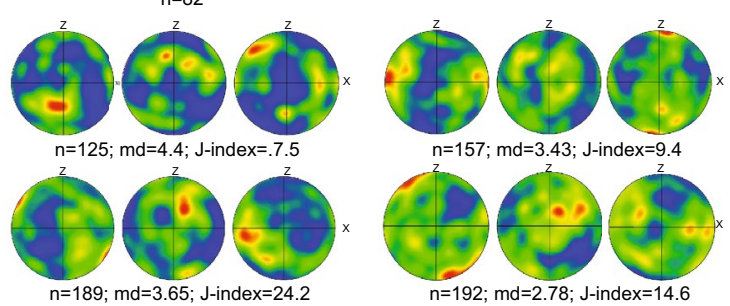

to those of olivine [100] and orthopyroxene [001] and to $\mathrm{X}$ (Fig. 8), showing that the clinopyroxene fabric is contemporaneous with that of the olivine-orthopyroxene framework. In contrast, lherzolites BFA17, BFA28, BFA43 show clinopyroxene [001] axes at high angle to olivine [100] and orthopyroxene [001] ones (Fig. 8), which indicates that the clinopyroxene fabric is later than that of the olivine-orthopyroxene framework.

Therefore, the CPO study shows that Befang lherzolites and harzburgite consist of an olivine-orthopyroxene framework, which records the high temperature deformation. Clinopyroxene is contemporaneous with this framework in harzburgite and part of the lherzolites, whereas in other lherzolites it was added later. This also applies to spinel, which is interstitial and has often amoeboidal shape, showing that the mineral was mobile when the texture of the host rock was formed. Spinel of this appearance can have various origins, e.g., Mercier and Nicolas (1975) interpreted similar textures (described by them as "vermicular exsolutions" and "holly leaf") as resulting from metamorphic recrystallization. In Befang, the amoeboidal spinel shape is well preserved and its grains do not show internal deformation (Fig. 9), indicating that after its crystallization the rock texture was not modified. The exception is large grain of spinel in lherzolite BFA33 (Fig. 9), which shows effects of deformation.

The spinel is Al-rich and its composition is very similar in most of the xenoliths (Fig. 6, Electronic Supplementary Material 3). We interpret these characteristics as the result of crystallization from a melt, consistent with prior interpretations of similar textures by e.g. Le Roux et al. (2007) or Builhol et al. (2009).

\section{Phase equilibria and geothermometric constraints}

Textural study shows that the olivine-orthopyroxene framework of the Befang lherzolites and harzburgite has similar fabric in all the rocks and records high-temperature deformation. This deformation is the oldest event recorded in the xenoliths. Subsequently, the Befang mantle was affected by percolation of melt, which deposited interstitial spinel. The clinopyroxene, which does not fit the olivine-orthopyroxene fabric in a part of xenoliths, supposedly also originated at the melt percolation stage. Now 

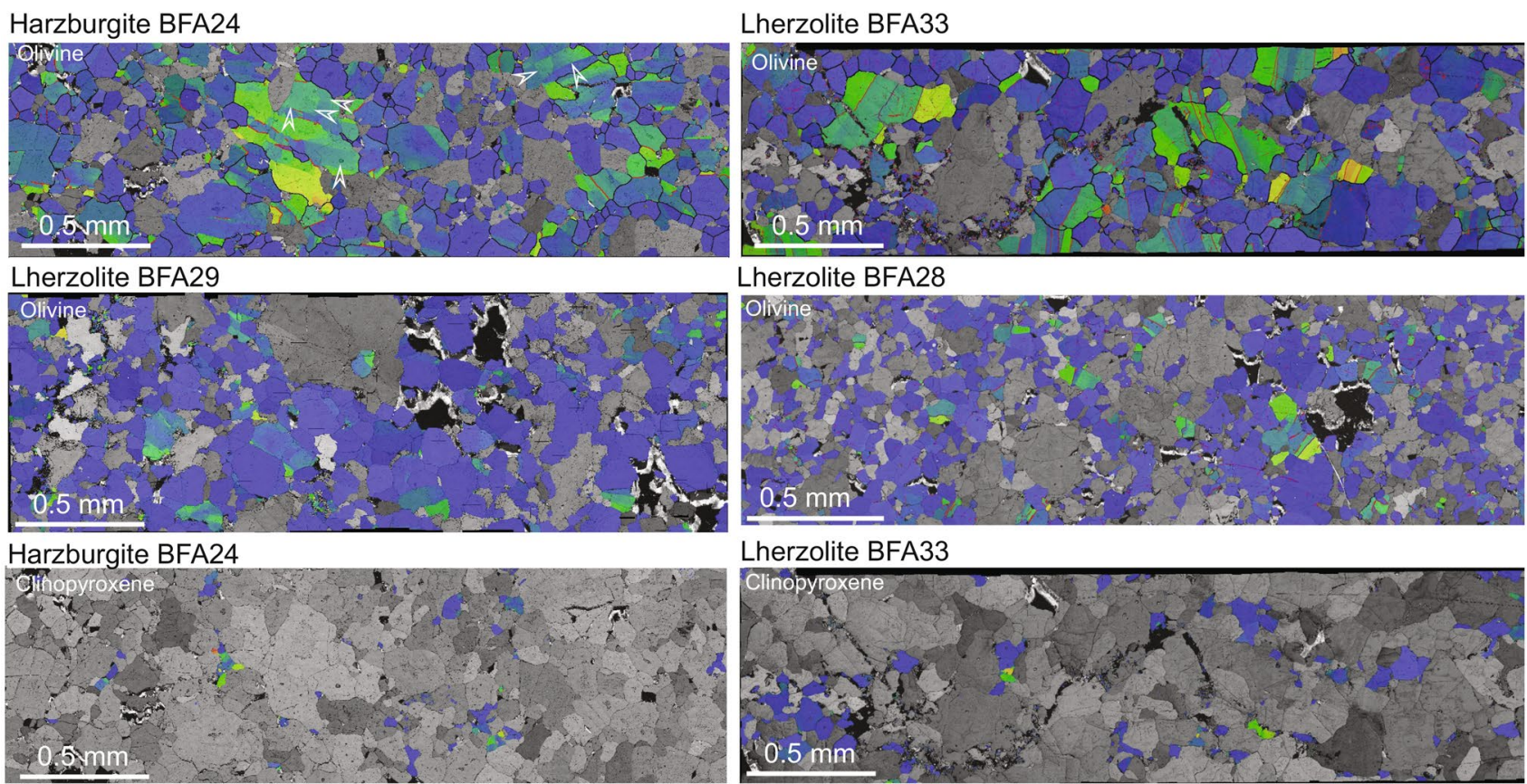

Lherzolite BFA33
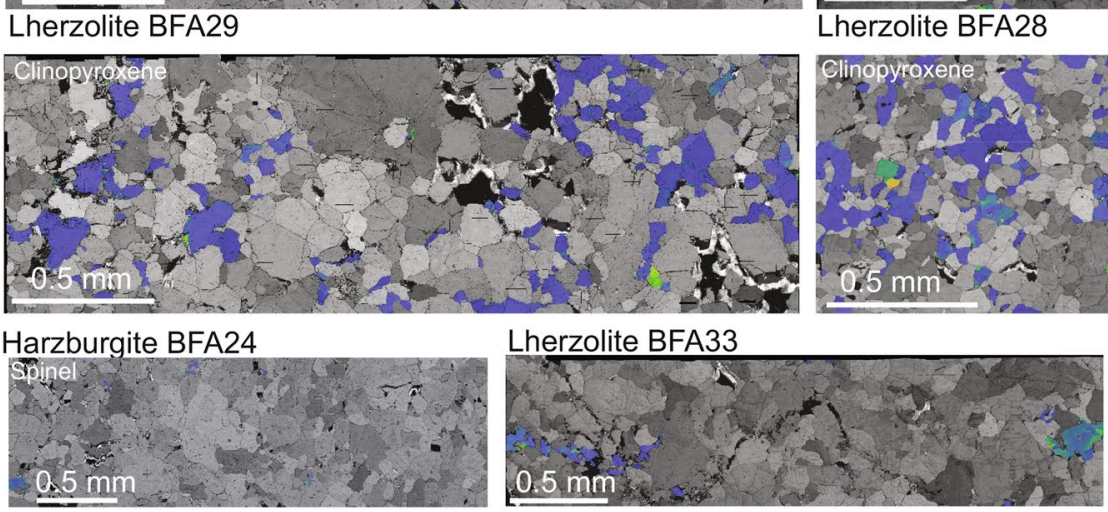

Fig. 9 Misorientation maps of olivine (a-d), clinopyroxene (e-h), and spinel (i-k) from harzburgite and lherzolites. The rainbow bar represents the misorientation scale. Blue indicates a value close to the mean grain orientation, while red colour indicates a deviation of $10^{\circ}$ or more from the mean grain orientation. Grains boundaries are black for $10^{\circ}$, purple for $5^{\circ}$ and red for $2^{\circ}$ we discuss how these constraints on mineral relationships can be joined with phase equilibria diagrams.

To discuss phase relationships relevant to the Befang peridotites, we use the thermodynamically calculated diagram of Jennings and Holland (2015), showing phase relationships in peridotite KLB-1. This rock, which is fertile in terms of major element composition, compares well to the Befang lherzolites. Owing to the chemical complexity of the modelled system, the phase diagram presented by Jennings and Holland (2015) is a reasonable analogue of natural rocks. This is supported by experimental studies relevant to spinel-facies mantle peridotite, which show similar phase relations and phase compositions in $\mathrm{P}-\mathrm{T}$ regions located above solidus (e.g., Falloon and Green 1987; Robinson et al. 1998).
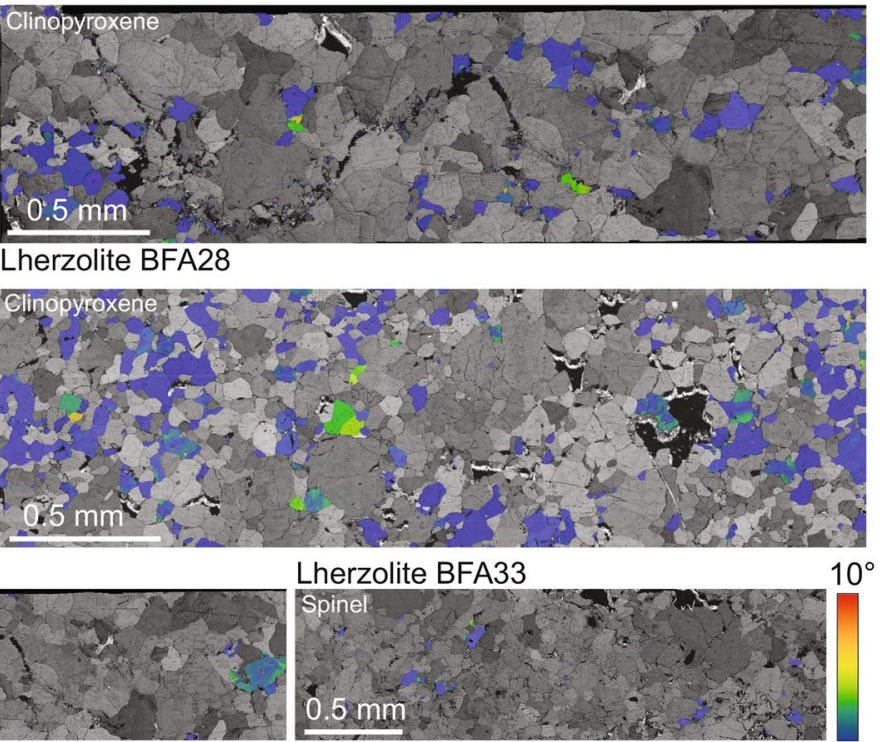

Lherzolite BFA28

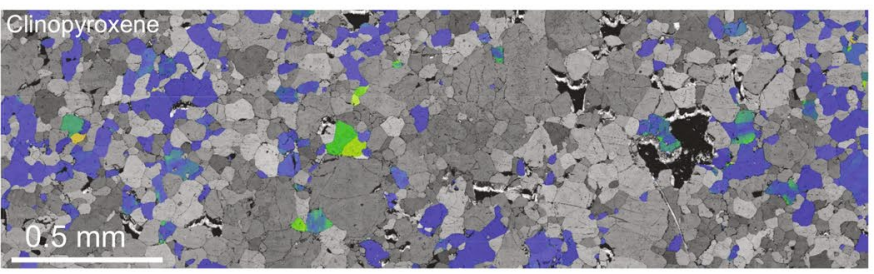

Spinel is stable at several tens of ${ }^{\circ} \mathrm{C}$ above the solidus during melting/crystallization of lherzolitic compositions under P-T conditions enabling spinel facies assemblages to be formed (Jennings and Holland 2015). Clinopyroxene is stable to temperatures up to $\sim 50{ }^{\circ} \mathrm{C}$ higher than those of spinel stability.

Since no hydrous phases occur in the Befang peridotites, we assume that the melt occurring in the Befang mantle section studied here contained insufficient concentrations of volatiles to saturate in hydrous minerals and the phase diagram relevant for dry conditions can be used. This sets the minimal temperatures of spinel and clinopyroxene crystallization at ca. $1200-1375^{\circ} \mathrm{C}$, corresponding to the solidus in a pressure interval of $1-2 \mathrm{GPa}$ (Fig. 1 in 
Jennings and Holland 2015; for a review of experimentally determined peridotite solidi, see Sarafian et al. 2017).

The temperatures of spinel and clinopyroxene crystallization indicated by phase relationships are significantly higher those yielded by two-pyroxene major and trace element geothermometers (Brey and Köhler 1990; Liang et al. 2013). Most of the Befang rocks record equilibration at temperatures of $950-1000{ }^{\circ} \mathrm{C}$ (Table 1). Harzburgite BFA24 and lherzolite BFA23 show even lower equilibration temperatures, between 930 and $940{ }^{\circ} \mathrm{C}$ (Table 1). At these temperatures, the spinel-facies mineral assemblages are stable in the narrow pressure interval of 1.0-1.4 GPa (Jennings and Holland 2015), corresponding to depths of $35-47 \mathrm{~km}$. We suggest that this is the depth range from which the xenoliths were entrained into the erupting lavas.

\section{Chemical evolution of the Befang mantle section}

Geothermometry shows that major and trace element contents in pyroxenes from the Befang xenoliths were reset during cooling. In the studied lherzolites, only LREE concentrations are varying in clinopyroxene among various samples (Fig. 7). The models of Sun and Liang (2014) show, however, that changes in LREE contents in clinopyroxene are small to negligible (see Fig. 6 in Sun and Liang 2014) during cooling of spinel facies lherzolites. Therefore, LREE variation in Befang clinopyroxenes supposedly was formed before cooling-related reequilibration.

Clinopyroxene REE characteristics and CPO define two kinds of lherzolites. The first one contains LREE-depleted clinopyroxene (group I in Fig. 7), the CPO of which is independent of the olivine-orthopyroxene host fabric (clinopyroxene [001] axes discordant to orthopyroxene [001] and olivine [100] axes, Fig. 8). This clinopyroxene supposedly crystallized (or recrystallized) during the melt percolation event.

The second kind of lherzolites (group II in Fig. 7) contains LREE-enriched clinopyroxene, the CPO of which is consistent with the olivine-orthopyroxene host fabric (clinopyroxene [001] axes are sub-parallel to olivine [100] and orthopyroxene [001] axes, suggesting coeval deformation. The CPO of this clinopyroxene represents the deformation recorded by the peridotite before melt percolation. The LREE-enriched lherzolites contain undeformed spinel which suggests that it was added by melt. The volume of this melt was too small to change the CPO of silicate framework. The exception is relatively large grain of spinel in lherzolite BFA33 (Fig. 9) which exhibits deformation, but has the composition similar to those of undeformed spinel grains. This suggests that spinel preserves its primary CPO even if its composition is resetted during melt percolation and/or cooling.
This indicates that the protolith of the lherzolites was subjected to reactive melt percolation (i.e., melt metasomatism) which led to replacement of LREE-enriched clinopyroxene by LREE-depleted one. During melt percolation, the aluminous spinel crystallized or replaced its less aluminous predecessor, and pyroxenes became saturated in $\mathrm{Al}$ at the level defined by spinel composition. This explains why the content of $\mathrm{Al}$ is similar in the clinopyroxene from lherzolites and (at a different level) in the orthopyroxene (Fig. 6). Thermometry shows that $\mathrm{Al}$ was redistributed between ortho- and clinopyroxene during cooling, but lherzolites remained saturated with $\mathrm{Al}$ at the level defined by spinel of $\mathrm{Cr} \# 0.09-0.11$ (Table 1).

The exceptions are harzburgite BFA24 and lherzolite BFA36, which contain spinel and clinopyroxene of slightly lower $\mathrm{Al}$ content (Table 1, Fig. 6). These two rocks probably document less advanced stages of the metasomatic process. The deformation recorded by olivine, orthopyroxene and clinopyroxene is coeval in the harzburgite (olivine [100] axes are sub-parallel to orthopyroxene [001] and clinopyroxene [001] axes), as in the lherzolites containing LREEenriched clinopyroxene.

The LREE redistribution process is frozen in lherzolite BFA29 belonging to the LREE-enriched group (Fig. 7). The olivine in this rock has the lowest forsterite content (ca. 88.7\%; Fig. 5) among all samples in this study. This is coupled with low $\mathrm{Mg} \#$ of ortho- and clinopyroxene, but there are no significant differences to other lherzolites in terms of mineral major element composition (Fig. 6). Representative samples of the LREE-enriched group (lherzolites BFA23 and BFA33) contain clinopyroxene the [001] axes of which are concordant to orthopyroxene [001] and olivine [100] axes (Fig. 8). This means that they preserved the CPO of their protolith. The lherzolite BFA29 CPO, however, is slightly more complex. It contains both clinopyroxene, the [001] axes of which are parallel to olivine [001] axes, and clinopyroxene the [001] axes of which are discordant relative to fabric defined by olivine-orthopyroxene (Fig. 8). The REE patterns of the BFA29 clinopyroxene are similar in HREE and MREE, but show three different "spoon-shaped" LREE levels occurring in different clinopyroxene grains (Fig. 7). The listed data on lherzolite BFA-29 show that: (1) metasomatism changed the major element composition of minerals (low Mg\#, Al-rich composition of pyroxenes); (2) the REE changes were slower than those of major elements; (3) at the initial stage, the orientation of clinopyroxene is similar to that of olivine-orthopyroxene framework, despite the changed major element composition. This suggests that this mineral replaces an older phase preserving its lattice orientation; (4) at a more advanced stage of metasomatism, the orientation of clinopyroxene becomes independent of olivine-orthopyroxene host. 
The REE patterns of orthopyroxene are approximately parallel to that of DMM orthopyroxene, but are shifted to lower REE contents (Fig. 7). The shift is not correlated with $\mathrm{T}_{\mathrm{REE}}$ (see Electronic Supplementary Material 8), which shows that it is not due to subsolidus cooling. The shift increases towards the LREEs part of the patterns, which suggests that it is caused by the same event which redistributed LREEs in clinopyroxene.

The Ti anomaly occurring in clinopyroxene is paired with that in orthopyroxene. The well-marked $\mathrm{Zr}-\mathrm{Hf}$ positive anomaly in orthopyroxene does not have a complementary negative counterpart in clinopyroxene (Fig. 7). Since thermometric calculations show that the minerals are chemically equilibrated, we suggest that this is an effect of concentrations. Titanium concentrations in pyroxenes are of similar order of magnitude, whereas those of $\mathrm{Zr}$ and $\mathrm{Hf}$ are lower in orthopyroxene by one order of magnitude relative to clinopyroxene. Therefore, the $\mathrm{Zr}$ and $\mathrm{Hf}$ anomalies in orthopyroxene may be too small to have a visible effect on clinopyroxene.

The former presence of melt explains well the very homogeneous major element mineral composition in the Befang lherzolites (olivine Fo content in all analyzed samples varies between 88.6 and 90.4 , orthopyroxene $\mathrm{Al}$ from 0.15 to 0.19 , clinopyroxene Al 0.24 to 0.29 , see Figs. 5, 6). The composition of spinel is aluminous and nearly constant $(\mathrm{Cr} \#$ 0.09-0.11; except harzburgite BFA24, Cr\# 0.19, and lherzolite BFA36, Cr\# 0.15; Table 1), and is typical for fertile assemblages (e.g., Workman and Hart 2005).

The major element analyses of minerals from peridotite xenoliths occurring in the nearby Nyos Lake (Liu et al. 2017, 2020; Pintér et al. 2015; Temdjim 2012) are more variable than those from Befang (Electronic Supplementary Material 4). On the other hand, the REE and trace element patterns of clino- and orthopyroxene (Lee et al. 1996; Liu et al. 2017, 2020; Pintér et al. 2015, Temdjim 2012) do not differ from those presented by us (Fig. 7).

\section{The nature of percolating melt}

To calculate REE characteristics of the percolating melt, we used the most LREE-depleted clinopyroxene (lherzolite BFA28) and partition coefficients of Yao et al. (2012) at $1300{ }^{\circ} \mathrm{C}$. We chose this rock because its clinopyroxene is most LREE-depleted and thus, according to our interpretations, originated from melt which is the least affected by changes due to reactive melt percolation. The calculated melt pattern is similar to N-MORB (Fig. 10) in that it is LREE-depleted, but the concentrations are higher and the MREE-HREE show a weak negative slope (Fig. 10; negative slope occurs in all melts calculated from clinopyroxene of group I, not shown here). These characteristics suggest that (1) the melt had a depleted mantle source similar to

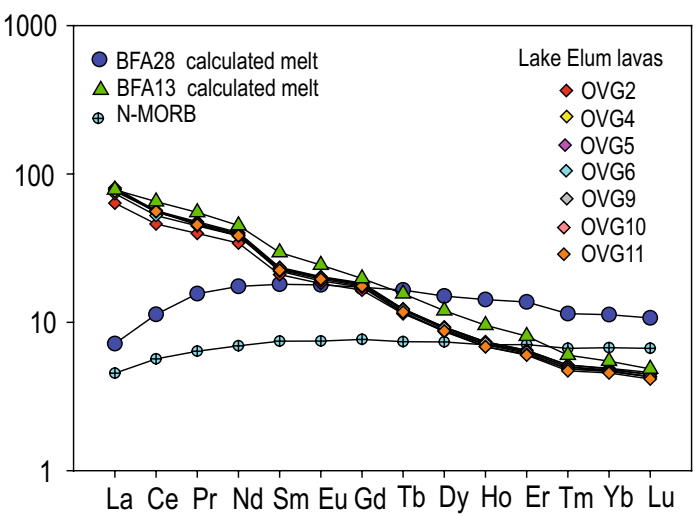

Fig. 10 Primitive mantle normalized (McDonough and Sun 1995) REE patterns of hypothetical melts in equilibrium with clinopyroxene from lherzolite BFA28 and websterite BFA13 compared with N-MORB (Arevalo Jr and McDonough 2010) and Oku volcanic rocks (Asaah et al. 2015, lavas OVG 2, 4, 5, 6, 9,10 and 11 from Lake Elum)

N-MORB and (2) the melt volume was smaller and formed in the presence of a small amount of garnet. Both observations can be explained considering that decompression melting during asthenospheric upwelling was limited due to the presence of a lithospheric lid (85-90 km at present; Goussi Ngalamo et al. 2018), whereas N-MORB forms by melting to $\leq 1.2 \mathrm{GPa}$ (Hirschmann and Stolper 1996). At 85-90 km depth (2.6-2.8 GPa) and for the inferred supersolidus temperature (minimum $1200-1275{ }^{\circ} \mathrm{C}$, as discussed above), depleted MORB mantle would contain a small amount of garnet (Ziberna et al. 2013), although the signature may also be produced by small amounts of pyroxenite in the source (Hirschmann and Stolper 1996) or by disequilibrium coupled with slow diffusion of trace elements (Oliveira et al. 2020).

Similar calculations for websterite BFA13 show that it may have originated by pyroxene precipitation from alkaline melts identical with those which occur in the nearby Lake Elum in the Oku volcano (Fig. 10). Therefore, websterite documents a synvolcanic stage of SCLM evolution. We speculate that websterites occur as veins which mark the alkaline lava pathways in the Befang lithospheric mantle.

\section{Reactive melt percolation}

Our interpretation of chemical and textural data on Befang mantle section shows that lherzolites originated by percolation of MORB-like melt in a harzburgitic protolith. This means that significant clinopyroxene must have been added, which requires efficient melt migration. After this metasomatic process, the Befang mantle section cooled and equilibrated in subsolidus temperatures $\left(930-1000{ }^{\circ} \mathrm{C}\right)$. The crystal-preferred orientations were not affected by cooling, but no textures related to melt percolation were preserved. 
Nevertheless, our interpretation is supported by experimental studies showing that silicate melt has low enough wetting angles to wet of peridotite minerals and, as a consequence, can easily migrate in peridotite interstices (e.g., Cmíral et al. 1998; Schäfer and Foley 2002). The example of lherzolite BFA29 (see section "Chemical evolution of the Befang mantle") shows that at the beginning of the process new clinopyroxene preserves the crystallographic orientation of its olivine-orthopyroxene framework, indicating epitaxial growth. All clinopyroxene of this type is LREE enriched. The more advanced stages produced LREE depleted clinopyroxene the crystallographic orientation of which is independent of the harzburgitic framework. Reactive melt percolation increases locally the melt fraction due to dissolution of host rock minerals, which enhances inter-grain migration of melt (Pec et al. 2017). We speculate that this mechanism allowed epitaxial growth of clinopyroxene (preserving CPO of its host) as well as its local crystallization from the melt (with new CPO).

Exposed sections of peridotite massifs show that reactive melt migration occurs in zones of few hundred to one thousand meters in which melt is penetrating into the protolith and reacting with it. Detailed descriptions come from Lherz (Le Roux et al. 2007, 2008), Ronda (Lenoir et al. 2001; Soustelle et al. 2009) and Beni Bousera (Frets et al. 2014; Varas-Reus et al. 2016) and show melt percolation which was syn- to late tectonic. Models postulating postdeformational addition of clinopyroxene to peridotites and defining the nature of "metasomatic agent" were presented in xenolith studies of Kaczmarek et al. (2016), Tommasi et al. (2008) and Zaffarana et al. (2014). By analogy, we assume that reactive melt percolation which we describe from the Befang xenolith suite was similar in nature. The different orientation of clinopyroxene relative to fabric of the olivine-orthopyroxene framework suggests that the Befang mantle section was subjected to melt percolation in a latetectonic regime.

\section{Conclusions}

The continental part of the Cameroon Volcanic Line is situated on the Central African Orogenic Belt. The underlying mantle lithosphere belongs to the spinel facies of mantle peridotites. Our study of the xenolith suite from Befang in the Oku Volcanic Group shows that it is dominated by lherzolites.

The Befang xenolith suite documents the following events in the lithospheric mantle underlying the Oku Volcanic Group (from oldest to youngest): (1) high-temperature deformation of the SCLM, (2) reactive percolation of melt of $\mathrm{N}-\mathrm{MORB}$ chemical affinity through the lithospheric mantle, (3) cooling at depths of 35-47 km, and (4) formation of websterite veins in the SCLM during alkaline volcanism in the OVG.

Melt percolation resulted in lherzolites which have chemical characteristics corresponding to Depleted MORB Mantle (sensu Workman and Hart 2005). However, rather than representing mantle that experienced a small degree of depletion, these lherzolites originated by refertilization by a depleted basaltic melt, similar to MORB. Thus, the Befang mantle section belongs to the group of mantle domains refertilised by DMM-derived melts, defined as "type 3" by Puziewicz et al. (2020).

Supplementary Information The online version contains supplementary material available at https://doi.org/10.1007/s00410-021-01796-3.

Acknowledgements We are grateful to two Anonymous Reviewers for their thoughtful comments which helped us to improve the final version of this paper, and to Dante Canil for editorial guidance. This study originated thanks to the project of Polish National Centre of Research NCN 2017/27/B/ST10/00365 to JP. The bilateral AustrianPolish project WTZ PL 08/2018 enabled extensive microprobe work. A. Proietti is thanked for help during EBSD measurements. FIERCE is financially supported by the Wilhelm and Else Heraeus Foundation and by the Deutsche Forschungsgemeinschaft (DFG, INST 161/921-1 FUGG and INST 161/923-1 FUGG), which is gratefully acknowledged. This is FIERCE contribution No. 61 .

Open Access This article is licensed under a Creative Commons Attribution 4.0 International License, which permits use, sharing, adaptation, distribution and reproduction in any medium or format, as long as you give appropriate credit to the original author(s) and the source, provide a link to the Creative Commons licence, and indicate if changes were made. The images or other third party material in this article are included in the article's Creative Commons licence, unless indicated otherwise in a credit line to the material. If material is not included in the article's Creative Commons licence and your intended use is not permitted by statutory regulation or exceeds the permitted use, you will need to obtain permission directly from the copyright holder. To view a copy of this licence, visit http://creativecommons.org/licenses/by/4.0/.

\section{References}

Abdelsalam MG, Liégeois J-P, Stern RJ (2002) The Saharan Metacraton. J Afr Earth Sc 34:119-136

ArevaloMcDonough RWF Jr (2010) Chemical variations and regional diversity observed in MORB. Chem Geol 271:70-85

Asaah ANE, Yokoyama T, Aka FT, Usui T, Kuritani T, Wirmvem MJ, Iwamori H, Fozing EM, Tamen J, Mofor GZ, Ohba T, Tanyileke G, Hell JV (2015) Geochemistry of lavas from maar-bearing volcanoes in the Oku Volcanic Group of the Cameroon Volcanic Line. Chem Geol 406:55-69

Aulbach S (2012) Craton nucleation and formation of thick lithospheric roots. Lithos 149:16-30

Aulbach S, Sun J, Tappe S, Höfer H, Gerdes A (2017) Volatile-rich metasomatism in the cratonic mantle beneath SW Greenland: link to kimberlites and mid-lithospheric discontinuities. J Petrol 58:2311-2338

Ben Ismaïl W, Mainprice D (1998) An olivine fabric database: an overview of upper mantle fabrics and seismic anisotropy. Tectonophysics 296:145-157 
Boyd FR (1989) Compositional distinction between oceanic and cratonic lithosphere. Earth Planet Sci Lett 96:12-26

Brey GP, Köhler T (1990) Geothermobarometry in four-phase lherzolites II. New thermobarometers and practical assessment of existing thermobarometers. J Petrol 31:1353-1378

Builhol P, Burg J-P, Bodinier J-L, Schmidt MW, Dawood H, Hussain S (2009) Magma and fluid percolation in arc to forearc mantle: evidence from Sapat (Kohistan, Northern Pakistan). Lithos 107:17-37

Bunge H-J (1982) Texture analysis in materials science: mathematical methods. Elsevier, Amsterdam

Bystricky M, Kunze K, Burlini L, Burg J-P (2000) High shear strain of olivine aggregates: rheological and seismic consequences. Science 290:1564-1567

Carlson RW, Ionov DA (2019) Compositional characteristics of the MORB mantle and bulk silicate Earth based on spinel peridotites from the Tariat region, Mongolia. Geochim Cosmochim Acta 257:206-223

Carlson RW, Pearson DG, James DE (2005) Physical, chemical and chronological characteristics of continental mantle. Rev Geophys 43:RG1001

Cmíral M, Fitz Geral JD, Faul UH, Green DH (1998) A close look at dihedral angles and melt geometry in olivine-basalt aggregates: a TEM study. Contrib Mineral Petrol 130:336-345

Deer WA, Howie RA, Zussman J (1992) An introduction to the rockforming minerals. Longman, New York, pp 1-696

Downes H, Reichow MK, Mason PRD, Beard AD, Thirlwall MF (2003) Mantle domains in the lithosphere beneath the French Massif Central: trace element and isotopic evidence from mantle clinopyroxenes. Chem Geol 200:71-87

Falloon TJ, Green DH (1987) Anhydrous partial melting of MORB pyrolite and other peridotite compositions at 10 kbar: implications for the origin of primitive MORB glasses. Mineral Petrol $37: 181-219$

Fishwick S (2010) Surface wave tomography: Imaging of the lithosphere-asthenosphere boundary beneath central and southern Africa? Lithos 120:63-73

Fitton JG (1980) The Benue trough an Cameroon line-a migrating rift system in West Africa. Earth Planet Sci Lett 51:132-138

Frets EC, Tommasi A, Garrido CJ, Vauchez A, Mainprice D, Targuisti K, Amri I (2014) The Beni Bousera peridotite (Rif Belt, Marocco): and oblique-slip low-angle shear zone thinning the subcontinental mantle lithosphere. J Petrol 55:283-313

Gallacher RJ, Bastow ID (2012) The development of magmatism along the Cameroon Volcanic Line: Evidence from teleseismic receiver functions. Tectonics 31:TC3018

Goussi Ngalamo JF, Sobh M, Bisso D, Abdelsalam MG, Atekwana E, Ekodeck GE (2018) Lithospheric structure beneath the Central Africa Orogenic Belt in Cameroon from the analysis of satellite gravity and passive seismic data. Tectonophysics 745:326-337

Griffin WL, O'Reilyy SY, Afonso JC, Begg GC (2009) The composition and evolution of lithospheric mantle. A re-evaluation and its tectonic implications. J Petrol 50:1185-1204

Hirschmann MM, Stolper EM (1996) A possible role for garnet pyroxenite in the origin of the "garnet signature"” in MORB. Contrib Miner Petrol 124:185-208

Jennings ES, Holland TJB (2015) A simple thermodynamic model for melting of peridotite in the system NCFMASOCr. J Petrol 56:869-892

Jochum KP, Weis U, Stoll B, Kuzmin D, Yang Q, Raczek I, Jacob DE, Stracke A, Birbaum K, Frick DA, Günther D, Enzweiler J (2011) Determination of reference values for NIST SRM 610-617 glasses following ISO guidelines. Geostand Geoanal Res 35:397-429

Jung H, Katayama I, Jiang Z, Hiraga T, Karato SI (2006) Effect of water and stress on the lattice-preferred orientation of olivine. Tectonophysics 421:1-22
Kaczmarek M-A, Reddy S (2013) Mantle deformation during rifting: constraints from quantitative microstructural analysis of olivine from the East African Rift (Marsabit, Kenya). Tectonophysics 608:1122-1137

Kaczmarek M-A, Bodinier J-L, Bosch D, Tommasi A, Dautria J-M, Kechid SA (2016) Metasomatized mantle xenoliths as a record of the lithospheric mantle evolution of the northern edge of the Ahaggar Swell, in Teria (Algeria). J Petrol 57:345-382

Karato S (2008) Deformation of earth materials: an introduction to rheology of solid earth. Cambridge University Press, Cambridge, pp 1-474

Le Roux V, Bodinier J-L, Tommasi A, Alard O, Dautria J-M, Vauchez A, Riches AJV (2007) The Lherz spinel lherzolite: refertilized rather than pristine mantle. Earth Planet Sci Lett 259:599-612

Le Roux V, Tommasi A, Vauchez A (2008) Feedback between melt percolation and deformation in an exhumed lithosphere-asthenosphere boundary. Earth Planet Sci Lett 274:401-413

Lee D-C, Halliday AN, Davies GR, Essene EJ, Fitton JG, Temdjim R (1996) Melt enrichment of shallow depleted mantle: a detailed petrological, trace element and isotopic study of mantle-derived xenoliths and megacrysts from the Cameroon Line. J Petrol 37:415-441

Lenoir X, Garrido CJ, Bodinier J-L, Dautria J-M (2000) Contrasting lithospheric mantle domains beneath the Massif Central (France) revealed by geochemistry of peridotite xenoliths. Earth Planet Sci Lett 181:359-375

Lenoir X, Garrido CJ, Bodinier J-L, Dautria J-M, Gervilla F (2001) The recrystallization front of the Ronda peridotite: evidence for melting and thermal erosion of subcontinental lithospheric mantle beneath the Alboran Basin. J Petrol 42:141-158

Liang Y, Sun C, Yao L (2013) A REE-in-two-pyroxene thermometer for mafic and ultramafic rocks. Geochim Cosmochim Acta 102:246-260

Liu C-Z, Yang L-Y, Li X-H, Tchounkoue JP (2017) Age and Sr-Nd$\mathrm{Hf}$ isotopes of the sub-continental lithospheric mantle beneath the Cameroon Volcanic Line: constraints from the Nyos mantle xenoliths. Chem Geol 455:84-97

Liu J, Pearson GJ, Shu Q, Sigurdsson H, Thomassot E, Alard O (2020) Dating post-Archean lithospheric mantle: insights from $\mathrm{Re}-\mathrm{Os}$ and $\mathrm{Lu}-\mathrm{Hf}$ isotopic systematics of the Cameroon Volcanic Line peridotites. Geochim Cosmochim Acta 278:177-198

Matsukage KN, Oya M (2010) Petrological and chemical variability of peridotite xenoliths from the Cameroon volcanic line, West Africa: an evidence for plume emplacement. J Mineral Petrol Sci 105:57-69

Matusiak-Małek M, Puziewicz J, Ntaflos T, Grégoire M, Benoit M, Klügel A (2014) Two contrasting lithologies in off-rift subcontinental lithospheric mantle beneath Central Europe-the Krzeniów (SW Poland) case study. J Petrol 55:1799-1828

McDonough W, Sun S (1995) The composition of the Earth. Chem Geol 120:223-253

Mercier JCC, Nicolas A (1975) Textures and fabrics of upper-mantle peridotites as illustrated by xenoliths from basalts. J Petrol $16: 454-487$

Nicolas A, Bouchez J-L, Boudier F, Mercier J-CC (1971) Textures, structures and fabrics due to solid state flow in some European lherzolites. Tectonophysics 12:55-86

Njome MS, De Wit MJ (2014) The Cameroon line: analysis of an intraplate magmatic province transecting both oceanic and continental lithospheres: constraints, controversies and models. Earth Sci Rev 139:168-194

O’Reilly SY, Zhang M, Griffin WL, Begg G, Hronsky J (2009) Ultradeep continental roots and their oceanic remnants: a solution to the geochemical "mantle reservoir" problem? Lithos 211S:1043-1054 
Oliveira B, Afonso JC, Tilhac R (2020) A disequilibrium reactive transport model for mantle magmatism. J Petrol 61. https://doi.org/10. 1093/petrology/egaa067

Pearson DG, Wittig N (2014) The formation and evolution of cratonic mantle lithosphere-evidence from mantle xenoliths. In: Holland HD, Turekian KK (eds) Treatise on geochemistry, vol 3, 2nd edn. Elsevier, Amsterdam, pp 255-292

Pearson DG, Canil D, Shirey SB (2003) Mantle samples included in volcanic rocks: xenoliths and diamonds. In: Treatise in geochemistry 1st edn, vol 2. Elsevier, Amsterdam, pp 171-275

Pec M, Holtzman BK, Zimmerman M, Kohlstedt DL (2017) Reaction infiltration instabilities in mantle rocks: and experimental investigation. J Petrol 58:979-1004

Pintér Z, Patkó L, Djoukam JFT, Kovács I, Tchouankoue JP, Falus G, Konc Z, Tommasi A, Barou F, Mihály J, Némrth C, Jeffries T (2015) Characterization of the sub-continental lithopsheric mantle beneath the Cameroon volcanic line inferred from alkaline basalts hosted peridotite xenoliths from Barombi Mbo and Nyos Lakes. J Afr Earth Sc 111:170-193

Puziewicz J, Matusiak-Małek M, Ntaflos T, Grégoire M, Kaczmarek M-A, Aulbach S, Ziobro M, Kukuła A (2020) Three major types of subcontinental lithospheric mantle beneath the Variscan orogen in Europe. Lithos 362-363:105467

Reusch AM, Nyblade AA, Wiens DA, Shore JP, Ateba B, Tabod CT, Nnange JM (2010) Upper mantle structure beneath Cameroon from body wave tomography and the origin of the Cameroon Volcanic Line. Geochem Geophys Geosyst 11:Q10W07

Robinson JAC, Wood BJ, Blundy JD (1998) The beginning of melting of fertile and depleted peridotite at 1.5 GPa. Earth Planet Sci Lett 155:97-111

Sarafian E, Gaetani GA, Hauri E, Sarafian AR (2017) Experimental constraints on the damp peridotite solidus and ocean mantle temperature. Science 355:942-945

Schäfer FN, Foley SF (2002) The effect of crystal orientation on the wetting behaviour of silicate melts on the surfaces of spinel peridotite minerals. Contrib Miner Petrol 143:254-261

Soustelle V, Tommasi A, Bodinier J-L, Garrido CJ, Vauchez A (2009) Deformation and reactive melt transport in the mantle lithosphere above a large-scale partial melting domain: the Ronda peridotite massif, Southern Spain. J Petrol 50:1325-1366

Sun C, Liang Y (2014) An assessment of subsolidus re-equilibration on REE distribution among mantle minerals olivine, orthopyroxene, clinopyroxene, and garnet in peridotites. Chem Geol 372:80-91

Temdjim R (2012) Ultramafic xenoliths from Lake Nyos area, Cameroon volcanic line, West-central Africa: Petrography, mineral chemistry, equilibration conditions and metasomatic features. Geochemistry 72(1):39-60
Tommasi A, Mainprice D, Canova G, Chastel Y (2000) Viscoplastic self-consistent and equilibrium-based modeling of olivine lattice preferred orientations: Implications for the upper mantle seismic anisotropy. J Geophys Res Solid Earth 105: 7893-7908

Tommasi A, Vauchez A, Ionov D (2008) Deformation, static recrystallization, and reactive melt transport in shallow subcontinental mantle xenoliths (Tok Cenozoic volcanic field, SE Siberia). Earth Planet Sci Lett 272:65-77

Toy V, Newman J, Lamb W, Tikoff B (2010) The role of oyroxenites in formation of shear instabilities in the mantle: Evidence from an ultramafic ultramylonite, Twin Sisters Massif, Washington. J Petrol 51:55-80

van Achterberg E, Ryan CG, Jackson SE, Griffin WL (2001) Data reduction software for LA-ICP-MS. In: Sylvester PJ (ed) Laser ablation ICPMS in the Earth sciences, principles and applications. Mineralogical Association of Canada, Short Course Series, vol 29, pp 239-243

Varas-Reus MI, Garrido CJ, Marchesi C, Bodinier J-L, Frets E, Bosch D, Tommasi A, Hida K, Targuisti K (2016) Refertilization processes in the subcontinental lithospheric mantle: the record of the Beni Bousera orogenic peridotite (Rif Belt, Northern Marocco). J Petrol 57:2251-2270

Workman RK, Hart SR (2005) Major and trace element composition of the depleted MORB mantle (DMM). Earth Planet Sci Lett 231:53-72

Yao L, Sun Ch, Liang Y (2012) A parameterized model for REE distribution between low-Ca pyroxene and basaltic melts with applications to REE partitioning in low-Ca pyroxene along a mantle adiabat and during pyroxenite-derived melt and peridotite interaction. Contrib Mineral Petrol 164:261-280

Zaffarana C, Tommasi A, Vauchez A, Grégoire M (2014) Microstructures and seismic properties of south Patagonian mantle xenoliths (Gobernador Gregores and Pali Aike). Tectonophysics 621:175-197

Zhang S, Karato S (1995) Lattice preferred orientation of olivine aggregates deformed in simple shear. Nature 375:774-777

Ziberna L, Klemme S, Nimis P (2013) Garnet and spinel in fertile and depleted mantle: insights from thermodynamic modelling. Contrib Miner Petrol 166:411-421

Publisher's Note Springer Nature remains neutral with regard to jurisdictional claims in published maps and institutional affiliations. 